\title{
Hot Cell Installation and Demonstration of the Severe Accident Test Station
}

Nuclear Technology

Research and Development

K. Linton

Y. Yan

Z. Burns

K. Terrani

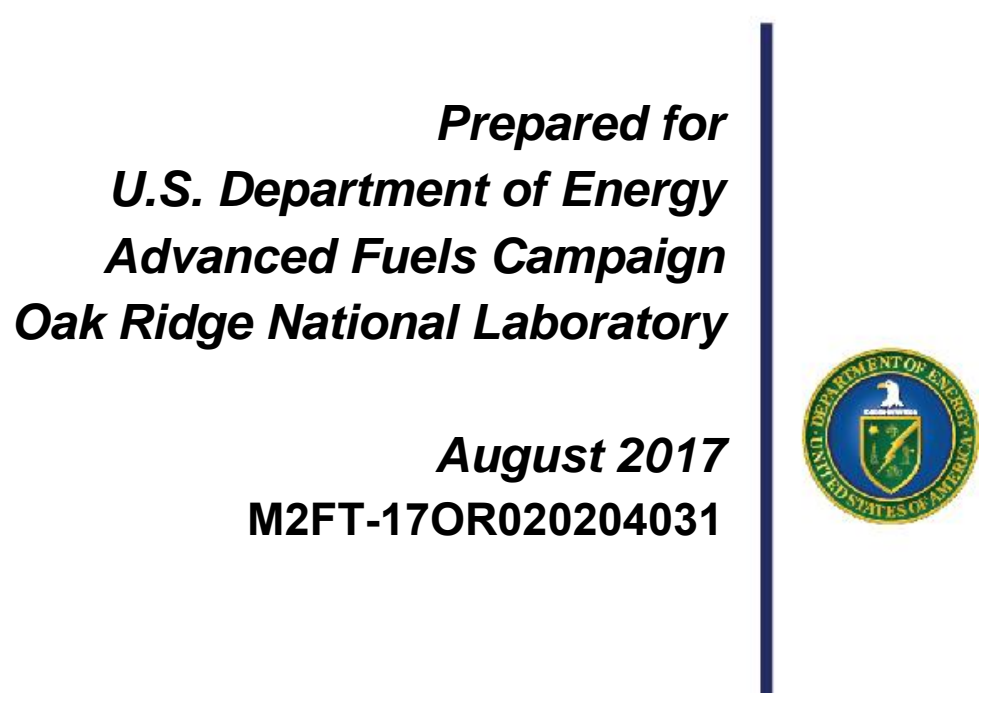





\section{DISCLAIMER}

This information was prepared as an account of work sponsored by an agency of the U.S. Government. Neither the U.S. Government nor any agency thereof, nor any of their employees, makes any warranty,

expressed or implied, or assumes any legal liability or responsibility for the accuracy, completeness, or usefulness, of any information, apparatus, product, or process disclosed, or represents that its use would not infringe privately owned rights. References herein to any specific commercial product, process, or service by trade name, trade mark, manufacturer, or otherwise, does not necessarily constitute or imply its endorsement, recommendation, or favoring by the U.S. Government or any agency thereof. The views and opinions of authors expressed herein do not necessarily state or reflect those of the U.S. Government or any agency thereof. 



\title{
Hot Cell Installation and Demonstration of the Severe Accident Test Station
}

\author{
K. Linton \\ Y. Yan \\ Z. Burns \\ K.A. Terrani
}

August 30, 2017

Prepared by

OAK RIDGE NATIONAL LABORATORY

Oak Ridge, TN 37831-6283

managed by

UT-BATTELLE, LLC

for the

US DEPARTMENT OF ENERGY

under contract DE-AC05-00OR22725 
Hot Cell Installation and Demonstration of the Severe Accident Test Station

August 2017

This page is intentionally left blank. 
ORNL/SPR-2017/434

Revision: 0

\section{SUMMARY}

A Severe Accident Test Station (SATS) capable of examining the oxidation kinetics and accident response of irradiated fuel and cladding materials for design basis accident (DBA) and beyond design basis accident (BDBA) scenarios has been successfully installed and demonstrated in the Irradiated Fuels Examination Laboratory, a hot cell facility at Oak Ridge National Laboratory. Two test station modules provide various temperature profiles, steam, and the thermal shock conditions necessary for integral lossof-coolant accident (LOCA) testing, defueled oxidation quench testing, and high-temperature BDBA testing. Installation of the SATS system restores the domestic capability to examine postulated and extended LOCA conditions on spent fuel and cladding and provides a platform for evaluating advanced fuel and accident-tolerant fuel cladding concepts.

This document reports on the successful in-cell demonstration testing of unirradiated Zircaloy-4. It also describes the integral test facility's capabilities, installation activities, and out-of-cell verification testing to calibrate and optimize the system. 
Hot Cell Installation and Demonstration of the Severe Accident Test Station

August 2017

This page is intentionally left blank. 


\section{CONTENTS}

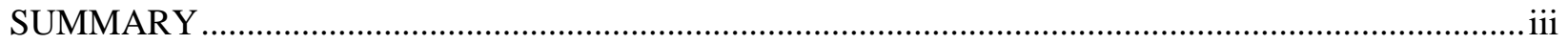

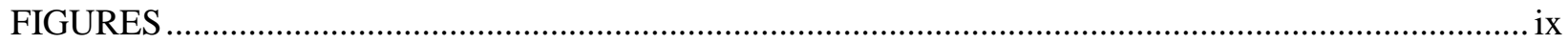

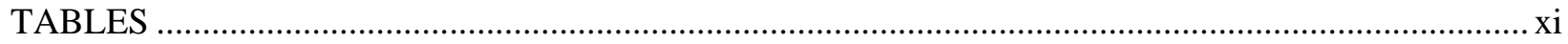

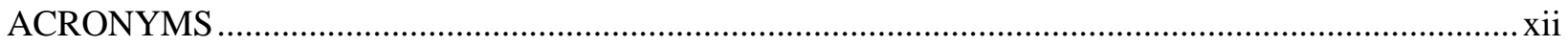

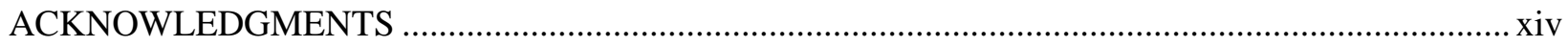

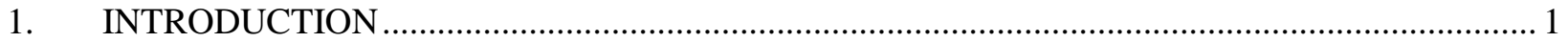

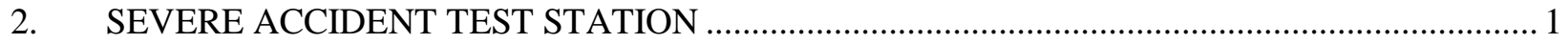

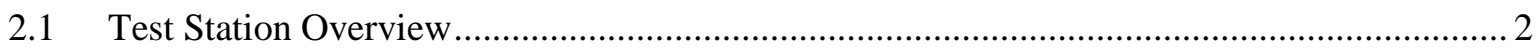

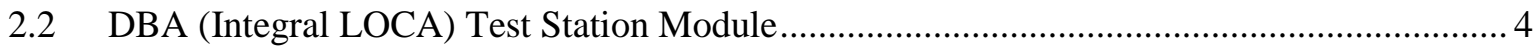

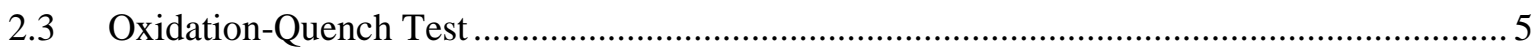

2.4 BDBA (High-Temperature) Test Station Module ............................................................ 5

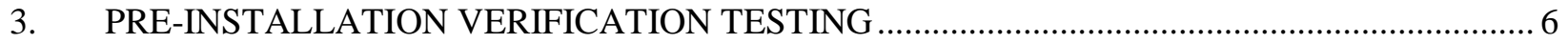

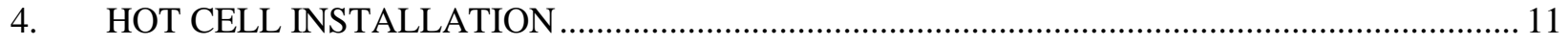

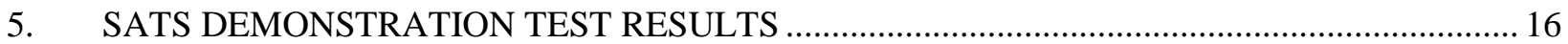

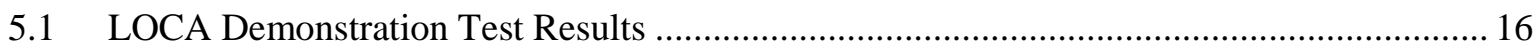

5.2 High-Temperature Furnace Demonstration Test Results ................................................ 17

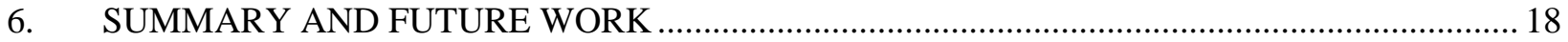

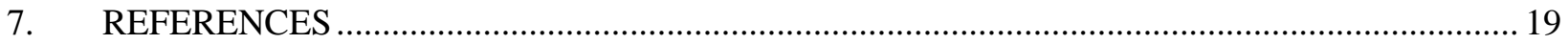


Hot Cell Installation and Demonstration of the Severe Accident Test Station

This page is intentionally left blank. 


\section{FIGURES}

Figure 1. (a) The Severe Accident Test Station is a single unit with two modules, one for design basis accident integral LOCA testing (outlined in blue) and one for beyond design basis accident high-temperature testing (outlined in red). (b) LOCA integral test apparatus.

Figure 2. LOCA test train.

Figure 3. Schematic of thermal history used for LOCA integral tests with 300-mm-long samples............5

Figure 4. High-temperature furnace and experiment schematic........................................................ 6

Figure 5. Two types of BDBA module high-purity alumina holders supporting short $(<50 \mathrm{~mm})$ cladding segments that are exposed to extreme temperatures $\left(>1600^{\circ} \mathrm{C}\right)$ and flowing steam or steam/gas mixtures

Figure 6. ORNL's integral LOCA furnace and test train within a quartz tube.

Figure 7. Verification testing of uniform temperature gradient at specimen centerline, which confirmed good agreement between thermocouple measurements. (a) Four type $\mathrm{S}$ thermocouples two were positioned at the specimen midplane $180^{\circ}$ apart, one was positioned $50 \mathrm{~mm}$ above the midplane, and one was positioned $50 \mathrm{~mm}$ below the midplane. (b) $10^{\circ} \mathrm{C} \Delta \mathrm{T}$ among four type $\mathrm{S}$ thermocouples

Figure 8. Comparison testing of strapped versus welded thermocouples. (a) Spot-welded thermocouple. (b) Strapped thermocouple. (c) The graph appears as one line because the temperature difference between the two methods is only $3^{\circ} \mathrm{C}$. These results provide confidence that either method will produce a uniform temperature reading. .............................. 8

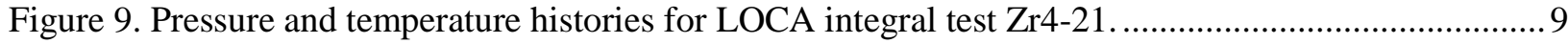

Figure 10. Top view (a) and side view (b) of four post-LOCA test samples tested at $1200^{\circ} \mathrm{C}$ with internal pressurization of 0.0, 4.14, 6.21, and 8.27 MPa. Close-up of (a): $\mathrm{Zr} 4-21$ at 6.21 MPa burst with maximum strain of $36.9 \%$. All maximum strain values are provided in Table 3 .

Figure 11. Overhead view of the Irradiated Fuels Examination Laboratory (IFEL), Building 3525. The Severe Accident Test Station faces workstation 5N (circled above) with the control cabinet positioned against the north operating wall.

Figure 12. SATS workstation before (a) and after (b) removing the radioactive materials. A lead sheet (painted white) was placed on the tabletop to reduce the dose rate.

Figure 13. A service plug for power line penetration through the hot cell wall. .13

Figure 14. Installation of a service plug for SATS into the hot cell wall .13

Figure 15. Installation of SATS into the main hot cell of the IFEL 14

Figure 16. SATS in the main hot cell of the IFEL 14

Figure 17. Water cooling system and high-pressure system for the in-cell LOCA apparatus. .15

Figure 18. A LOCA test train within a quartz tube. .16

Figure 19. LOCA in-cell demonstration test in the IFEL. .16

Figure 20. Pressure and temperature histories for in-cell LOCA integral test Zr4-26. .17

Figure 21. Temperature history for the in-cell high-temperature steam oxidation test performed August 3, 2017. 
Hot Cell Installation and Demonstration of the Severe Accident Test Station

Figure 22. ATF-1 rodlet irradiated in ATR, with $\mathrm{FeCrAl}$ cladding and $\mathrm{UO}_{2}$ pellets designed for post-irradiation testing using SATS. 18 


\section{TABLES}

Table 1. Summary of domestic and international accident testing capabilities ........................................ 2

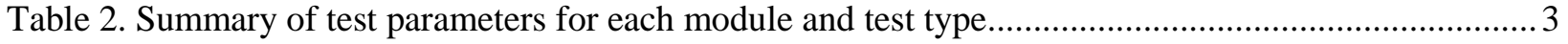

Table 3. LOCA integral test results for unirradiated Zircaloy-4 cladding filled with zirconia pellets. 


\section{ACRONYMS}

$\begin{array}{ll}\text { ANL } & \text { Argonne National Laboratory } \\ \text { ATF } & \text { accident-tolerant fuel } \\ \text { ATR } & \text { Advanced Test Reactor (at Idaho National Laboratory) } \\ \text { BDBA } & \text { beyond design basis accident } \\ \text { DBA } & \text { design basis accident } \\ \text { ECR } & \text { equivalent clad reacted } \\ \text { IFEL } & \text { Irradiated Fuels Examination Laboratory } \\ \text { INL } & \text { Idaho National Laboratory } \\ \text { LOCA } & \text { loss-of-coolant accident } \\ \text { R } & \text { roentgen } \\ \text { SATS } & \text { Severe Accident Test Station } \\ \text { TREAT } & \text { Transient Reactor Test Facility (at Idaho National Laboratory) }\end{array}$


This page is intentionally left blank. 


\section{ACKNOWLEDGMENTS}

This work was supported by the Advanced Fuels Campaign of the US Department of Energy Office of Nuclear Energy. The authors would like to express appreciation to J. Keiser and M. Howell of the ORNL Materials Science and Technology Division for their support and expertise throughout the process of establishing this in-cell capability. We are grateful to Dr. Ken Yueh of the Electric Power Research Institute for providing Zircaloy-4 tubing. 
This page is intentionally left blank. 



\section{HOT CELL INSTALLATION AND DEMONSTRATION OF THE SEVERE ACCIDENT TEST STATION}

\section{INTRODUCTION}

The Severe Accident Test Station (SATS), installed at the Irradiated Fuels Examination Facility (IFEL), a hot cell facility in Building 3525 of Oak Ridge National Laboratory (ORNL), is an integral test facility capable of studying the response of irradiated fuels and materials to design basis accident (DBA) and beyond design basis accident (BDBA) scenarios. The motivation behind the development of this capability lies in restoring a domestic capability to perform integral testing of irradiated materials and to evaluate advanced nuclear fuel cladding concepts with enhanced accident tolerance in what is known as accident-tolerant fuel (ATF). The in-cell capability provides a platform for evaluation of cladding structural integrity, which is the first barrier for retention of fission products in light water reactor cores.

The high-temperature steam oxidation behavior of zirconium alloy cladding under design basis loss-ofcoolant accidents (LOCA) and over a broader set of conditions has been studied at several facilities around the world ([1]-[8]). Currently only a limited number of facilities domestically and internationally can examine the oxidation behavior and post-quench ductility of cladding materials (Table 1). DBA evaluation of Zr-based alloys using the LOCA Integral Test system was originally developed at Argonne National Laboratory (ANL) and provided significant contribution to the US Nuclear Regulatory Commission test criteria for LOCAs [5]. After the ANL unit was decommissioned, the domestic capability was lost. In the aftermath of the Tōhoku earthquake and tsunami and the resulting Fukushima Daiichi nuclear accident, research goals have been directed towards developing novel materials with enhanced accident tolerance in light water reactor designs. These materials require evaluation in comparison to current $\mathrm{UO}_{2} / \mathrm{Zr}$-based alloy fuel systems to understand the DBA response and enhanced safety margins of BDBA scenarios.

To develop a single platform capable of evaluating both DBA and BDBA scenarios, design parameters were discussed and developed in two workshops in 2012, the Severe Accident Test Station Definition Workshop in San Diego, and the International Meeting on Examination of Current and Advanced Nuclear Fuels under Simulated Accident Conditions in Berkeley, California. The test station currently deployed in Building 3525 and described in this document is the outcome of design input from these workshops. The test station, which includes two modules on a single test stand, is capable of various temperature profiles, steam, and the thermal shock conditions necessary for LOCA testing, defueled oxidation quench testing, and high-temperature BDBA testing. This milestone report documents the in-cell capabilities of the SATS system, benchmark testing, installation, and demonstration testing at ORNL.

\section{SEVERE ACCIDENT TEST STATION}

As shown in Table 1, SATS is an internationally unique capability combining already developed out-ofcell testing capabilities with an in-cell integral LOCA test apparatus and a high-temperature BDBA furnace for examining oxidation behavior and post-quench ductility of fuel rod segments. This section briefly describes the testing capabilities of SATS's two modules. 
Table 1. Summary of domestic and international accident testing capabilities

\begin{tabular}{|c|c|c|c|c|c|c|c|c|}
\hline Lab & $\begin{array}{c}\text { Heating } \\
\text { method }\end{array}$ & $\begin{array}{c}\text { Temperature } \\
\text { control }\end{array}$ & $\begin{array}{c}\text { Temperature } \\
\text { measurement }\end{array}$ & $\begin{array}{c}\text { Out of } \\
\text { cell }\end{array}$ & In cell & Fuel & $\begin{array}{c}\text { Target } \\
\text { maximum } \\
\text { temperature } \\
\left({ }^{\circ} \mathbf{C}\right)\end{array}$ & Ref. \# \\
\hline ORNL SATS & $\begin{array}{c}\text { Radiant }+ \\
\text { (resistance) }\end{array}$ & Computer & Thermocouples & Yes & Yes & Yes & $1200(1700)$ & $\begin{array}{c}\text { This } \\
\text { work }\end{array}$ \\
\hline ANL & Radiant & Computer & Thermocouples & Yes & Yes & No & 1200 & {$[3],[5]$} \\
\hline CEA-Saclay & Resistance & Manual & Pre-set & Yes & No & No & 1200 & {$[6]$} \\
\hline Halden & $\begin{array}{c}\text { Reactor }+ \\
\text { heaters }\end{array}$ & Pre-set & Thermocouples & No & No & Yes & 1200 & {$[9]$} \\
\hline JAEA & Radiant & Computer & Thermocouples & Yes & Yes & No & 1200 & {$[4],[10]$} \\
\hline Studsvik & Radiant & Computer & Thermocouples & No & Yes & Yes & 1200 & {$[11]$} \\
\hline
\end{tabular}

The working principles and a detailed review of SATS are described in an exhaustive design report from FY 2015 [12]. Sections 2.1 through 2.4, describing each module and testing type, are reproduced here from that report in summary form for the convenience of the reader.

\subsection{Test Station Overview}

Figure 1 provides an overview of the test station prior to in-cell insertion; it consists of two modules on a single test stand. The integral LOCA test apparatus is outlined in blue, while the high-temperature test furnace is outlined in red. The SATS system was initially deployed out-of-cell to examine nonirradiated materials. The same modules were then replicated and modified for in-cell operation (i.e., in ORNL's fuel hot cell in Building 3525) to examine irradiated fuels and materials. Throughout the design of the SATS system, operational constraints within the hot cell (e.g., spatial and other constraints from the use of manipulators to operate the unit, and limits on the volume and types of gases released from the system) have been thoroughly captured to enable an efficient transition from the out-of-cell module to the in-cell capability. Table 2 summarizes the range of test parameters for each module and test type. 


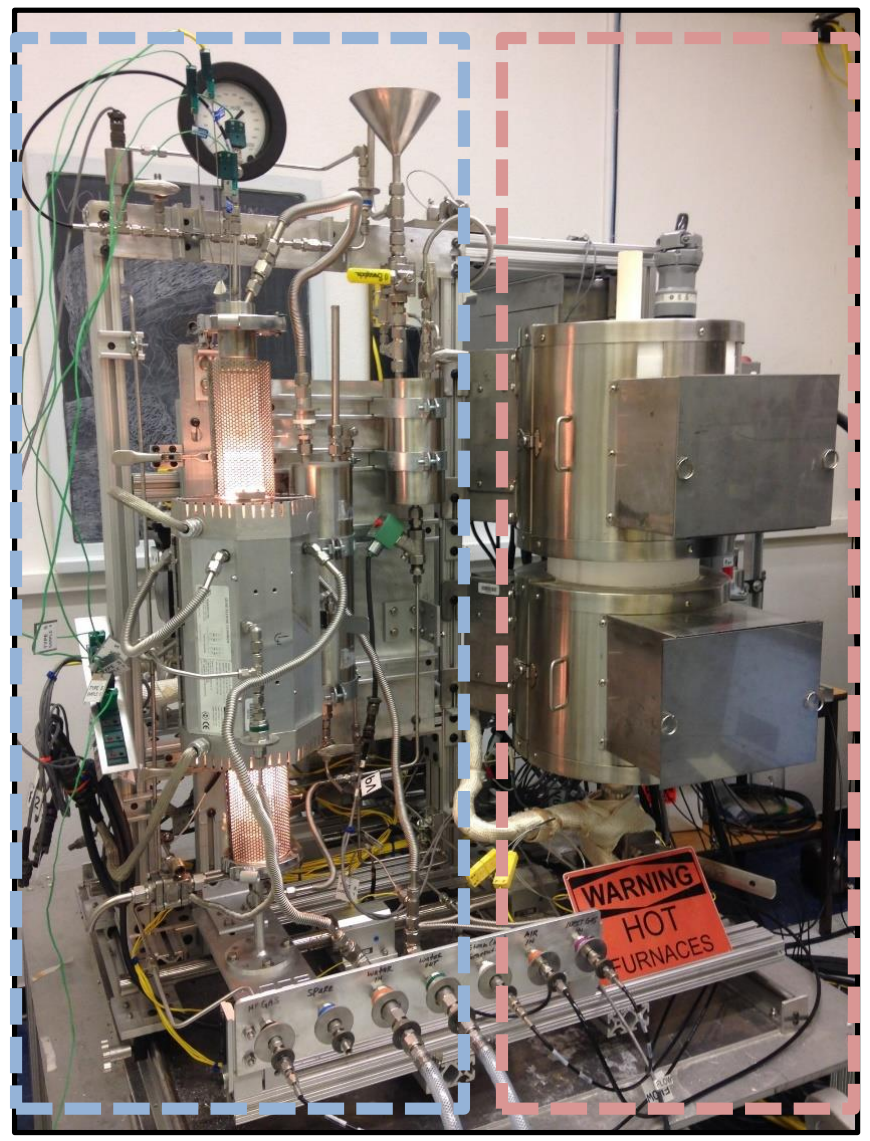

(a)

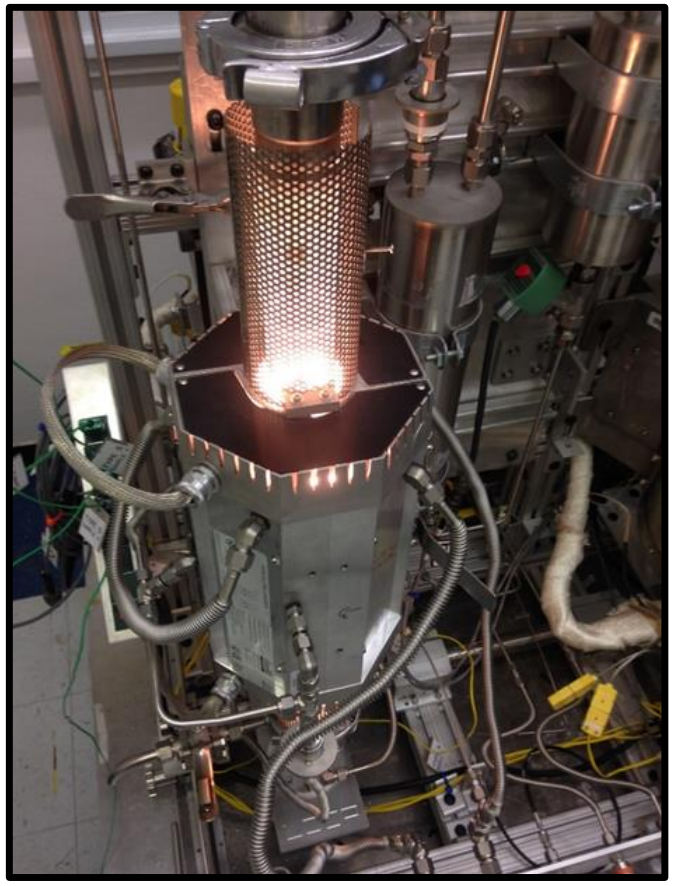

(b)

Figure 1. (a) The Severe Accident Test Station is a single unit with two modules, one for design basis accident integral LOCA testing (outlined in blue) and one for beyond design basis accident hightemperature testing (outlined in red). (b) LOCA integral test apparatus.

Table 2. Summary of test parameters for each module and test type

\begin{tabular}{|l|c|c|c|}
\hline \multirow{2}{*}{} & \multicolumn{2}{|c|}{ DBA module } & BDBA module \\
\cline { 2 - 4 } & LOCA integral test & Oxidation-quench test & $\begin{array}{c}\text { High-temperature test } \\
\text { station }\end{array}$ \\
\hline Sample spec & Fueled rod & Defueled rod & $\begin{array}{c}\text { Rod or coupon with } \\
\text { mm hole }\end{array}$ \\
\hline Sample segment, $\mathrm{mm}$ & $\sim 200-300$ & $\sim 25-50$ & $\sim 25-50$ \\
\hline Pressure, $\mathrm{MPa}$ & $\sim 8, \max 20$ & 0.1 & 0.1 \\
\hline Max temp, ${ }^{\circ} \mathrm{C}$ & 1200 & 1200 & $\mathbf{1 7 0 0}$ \\
\hline Heating rate, ${ }^{\circ} \mathrm{C} / \mathrm{s}$ & 5 & $5 ;$ max 20 & $3.0-7.0$ \\
\hline Steam flow rate, $\mathrm{mg} / \mathrm{cm}^{2} \cdot \mathrm{s}$ & $\sim 5.7$ & Steam or argon .33 \\
\hline Gas environment & Steam or argon & @ $20-800$ & Steam or argon \\
\hline Quench, ${ }^{\circ} \mathrm{C}$ & $@ 20-800$ & Rising water around & None \\
\hline Quench condition & Rising water around & None \\
\hline Quench flow rate, $\mathrm{mm} / \mathrm{s}$ & $\geq 15$ & $\geq 15$ & None \\
\hline Test time, min & $\geq 30$ & $\geq 30$ & Multiple days \\
\hline
\end{tabular}




\subsection{DBA (Integral LOCA) Test Station Module}

The US Code of Federal Regulations covers postulated LOCAs in 10 CFR 50.46. LOCA integral tests were designed to investigate the performance of high-burnup irradiated fuel that has undergone ballooning and rupture under LOCA conditions. The LOCA integral test train was designed to externally heat a 300 -mm-long fuel rod segment up to $1200^{\circ} \mathrm{C}$ by an infrared (IR) radiation furnace under initial high internal pressure ( $\sim 8 \mathrm{MPa}$ inside the tube). The internal pressure is generated by high-pressure argon gas, and the pressure is monitored using a digital output pressure transducer.

Temperature control and monitoring are extremely important in conducting LOCA integral and oxidation quench tests, because the time at temperature for the transition between ductile and brittle behavior is a strong function of temperature. The furnace power and the sample temperature are controlled by feedback from the designated type $\mathrm{S}(\mathrm{Pt} / \mathrm{Pt}-\mathrm{Rh})$ thermocouple output through a proportional-integral-differential (PID) controller to the furnace power. Each test sample is fitted with up to four thermocouples, two placed at the specimen midplane $180^{\circ}$ apart, one positioned $50 \mathrm{~mm}$ above the midplane, and one positioned $50 \mathrm{~mm}$ below the midplane. Sample heat-up occurs quickly for short samples, but temperature overshoot can be avoided by an integrated and well-instrumented control system.

A quartz tube provides an enclosed volume for steam flow and water quench of the $300 \mathrm{~mm}$ rod segment; both steam and water are introduced through the bottom of the unit. The test train is centered within the quartz tube by means of two perforated spacer disks. Swagelok fittings are used above the specimen to connect to the highpressure gas line and top pressure gauge, and below the specimen to connect to the bottom pressure-gauge line. The test train for the LOCA integral tests is supported at the top to minimize specimen bowing. Figure 2. LOCA test train. provides more detail of the test train.

Figure 3 shows a schematic of the temperature history of the LOCA integral tests used for both out-of-cell and in-cell testing. Because of the high thermal mass of the sample and the thermocouples welded (nonirradiated) or wrapped (irradiated) around the LOCA sample, temperature control is easier than for the short, defueled cladding oxidation-quench samples (see the temperature history in Figure 1). For example, the reference control parameters for current boiling water reactor cladding are $8.28 \mathrm{MPa}(1200 \mathrm{psig})$ internal pressure with argon at room temperature and $300^{\circ} \mathrm{C}, 5^{\circ} \mathrm{C} / \mathrm{s}$ heating rate, $1200^{\circ} \mathrm{C}$ hold temperature, variable hold time, $3^{\circ} \mathrm{C} / \mathrm{s}$ cooling rate from the hold temperature to $800^{\circ} \mathrm{C}$, and rapid cooling from bottomflooding water quench at $800^{\circ} \mathrm{C}$.

As these parameters are controlled by software (LabView), they can be adjusted from test to test. Online data of interest include the time response of the bottom pressure transducer at room temperature and $300^{\circ} \mathrm{C}$, burst temperature, and burst pressure.

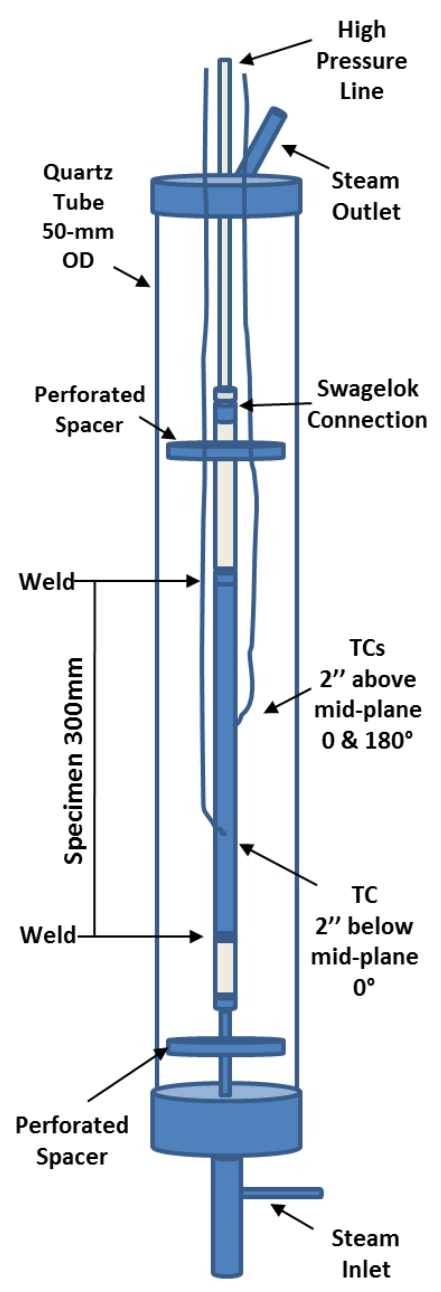

Figure 2. LOCA test train. 


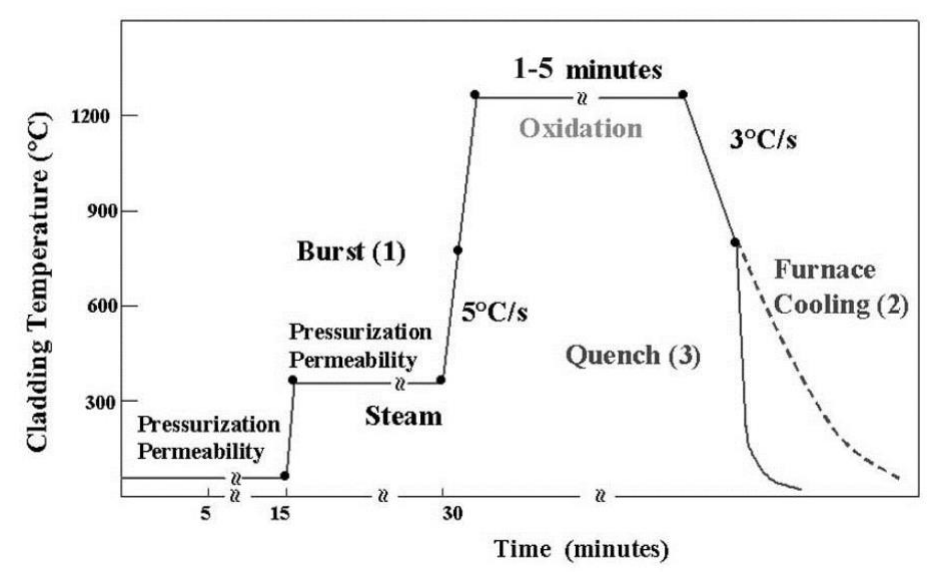

Figure 3. Schematic of thermal history used for LOCA integral tests with 300-mm-long samples.

\subsection{Oxidation-Quench Test}

Oxidation tests conducted on defueled high-burnup cladding samples are needed to characterize the evolution with time at temperature of the oxygen pickup and of the oxide thickness and morphology. The oxidized high-burnup samples are also used to determine post-test ductility as a function of corrosion layer thickness, hydrogen content, and high-temperature oxidation level. These data are used as a guideline to determine the test parameters of the LOCA integral tests.

Oxidation-quench tests do not require a high-pressure connection or pressure transducers. Steam, at nearatmospheric pressure, flows up through the quartz-tube test chamber at $0.32 \pm 0.05 \mathrm{~g} / \mathrm{cm}^{2} / \mathrm{min}(5.3 \mathrm{~g} / \mathrm{min}$ for a $48 \mathrm{~mm}$ internal diameter quartz tube) and exits the chamber into a condenser or exhaust. Following oxidation and slow-cooling phases, steam flow is turned off, and quench water is introduced through the bottom of the quartz tube, filling the tube to provide very rapid sample cooling to $70-100^{\circ} \mathrm{C}$ at the desired time and temperature during cooling. NRC-specified temperature profiles for the oxidation-quest testing using the ANL-proposed procedure include temperatures up to $1200^{\circ} \mathrm{C}$ and a ramp rate of $\geq 20^{\circ} \mathrm{C} / \mathrm{s}$, starting from $300^{\circ} \mathrm{C}$, to within $200^{\circ} \mathrm{C}$ of the target temperature and $\geq 2{ }^{\circ} \mathrm{C} / \mathrm{s}$ thereafter [3]. The cooling rate is known to significantly affect the post-quench ductility of the oxidized samples [13], and exact details on how post-quench ductility is affected by the cooling rate are not fully understood. The recommended average cooling rate to the $800^{\circ} \mathrm{C}$ quench temperature is $\approx 12 \pm 2^{\circ} \mathrm{C} / \mathrm{s}$.

The LOCA module of the SATS system was designed and built to meet all requirements for these oxidation test parameters. By fabricating oxidation test trains and performing benchmarking tests using both the out-of-cell and in-cell test stations at ORNL, the oxidation-quest test can also be made available for irradiated fuels and materials research.

\subsection{BDBA (High-Temperature) Test Station Module}

The objective of the high-temperature test station module is to provide a facility where samples of candidate fuel and cladding materials can be exposed to conditions more severe than the generally recognized LOCA test conditions. More specifically, the system is capable of exposing samples to rapidly flowing steam or a steam/gas mixture at temperatures of at least $1600^{\circ} \mathrm{C}$. For this system, two molybdenum disilicide, resistance-heated, clamshell furnaces were chosen to create the very high temperature environment used for sample exposure (see Figure 1). The system is suitable for testing short sections of a radioactive fuel rod hanging from high-purity alumina holders as shown in Figure 4 and Figure 5 . 


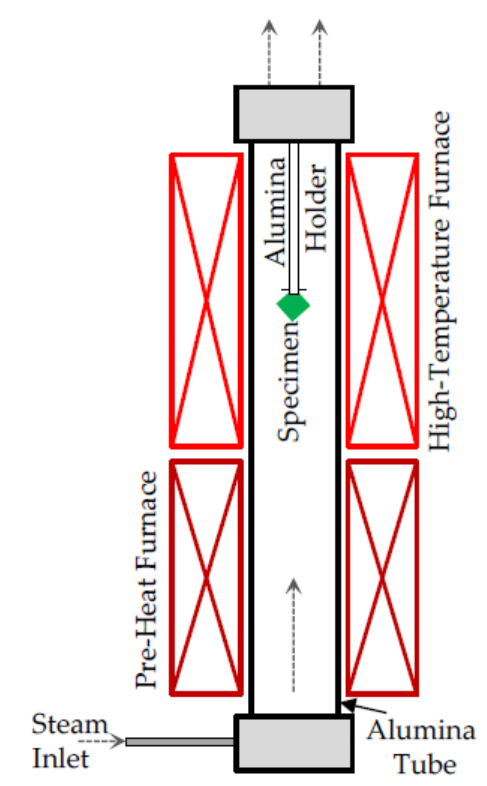

Figure 4. High-temperature furnace and experiment schematic.
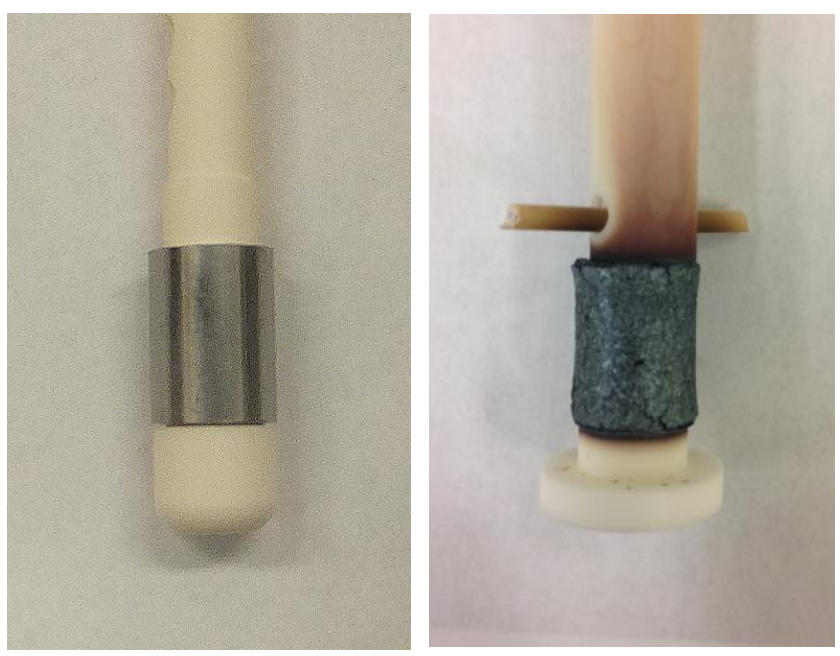

Figure 5. Two types of BDBA module high-purity alumina holders supporting short $(<50 \mathrm{~mm})$ cladding segments that are exposed to extreme temperatures $\left(>1600^{\circ} \mathrm{C}\right)$ and flowing steam or steam/gas mixtures.

\section{PRE-INSTALLATION VERIFICATION TESTING}

Before moving the SATS system into the hot cell, many thermal verification LOCA tests were performed to aid in optimizing the apparatus and the test train for remote operation in the hot cell. These tests were conducted with specimens made from $17 \times 17$ pressurized water reactor Zircaloy-4 (300 mm long, 9.50 $\mathrm{mm}$ outer diameter, $0.570 \mathrm{~mm}$ wall thickness) filled with dense zirconia pellets leaving a cold radial gap of $\approx 0.1 \mathrm{~mm}$. For the quad-elliptic radiant furnace, specimen bowing induced significant axial $\left(\Delta T_{\mathrm{z}}\right)$ and circumferential $\left(\Delta T_{\theta}\right)$ variations in temperature. This problem was solved by supporting the test train at the top. 
Figure 6 shows a LOCA sample within the test chamber of the LOCA apparatus. The quartz tube encasing the test train provides an enclosed volume for steam flow and water quench, both of which are introduced through the bottom of the test train. The total gas volume in the test sample is $10 \mathrm{~cm}^{3}$, most of which is outside the heated zone. To verify uniform temperature across the centerline of the LOCA test specimen, benchmark testing was conducted with four type $S$ thermocouple lead wires fed through the top flange: two were positioned at the specimen midplane $180^{\circ}$ apart, one was positioned $50 \mathrm{~mm}$ above the midplane, and one was positioned $50 \mathrm{~mm}$ below the midplane (Figure 7a). These thermocouples are accurate to $\pm 3^{\circ} \mathrm{C}$ at $1200^{\circ} \mathrm{C}$. The tests showed a $10^{\circ} \mathrm{C}$ variation in temperature $(\Delta T)$ at these four locations during a full LOCA test (Figure 7b), confirming a uniform temperature across the centerline.

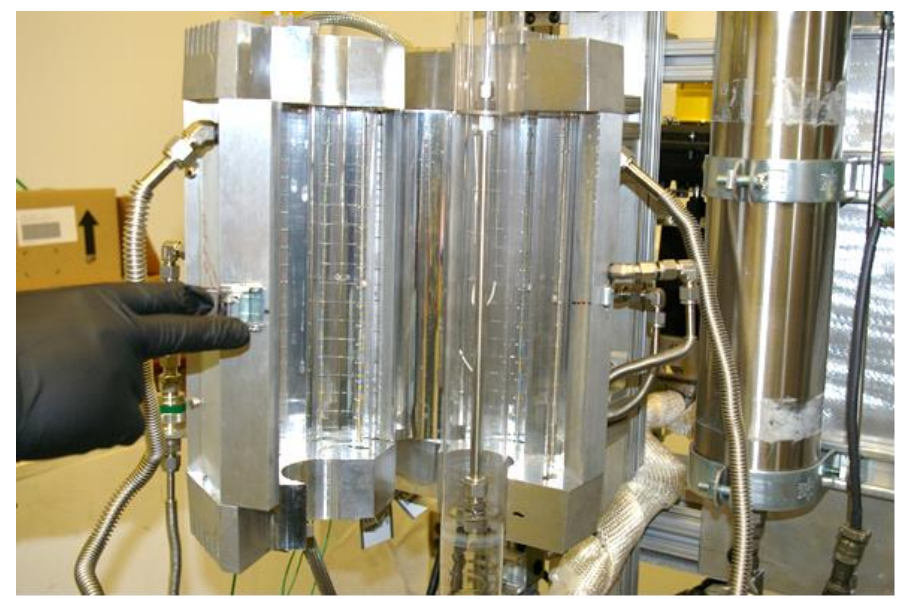

Figure 6. ORNL's integral LOCA furnace and test train within a quartz tube.

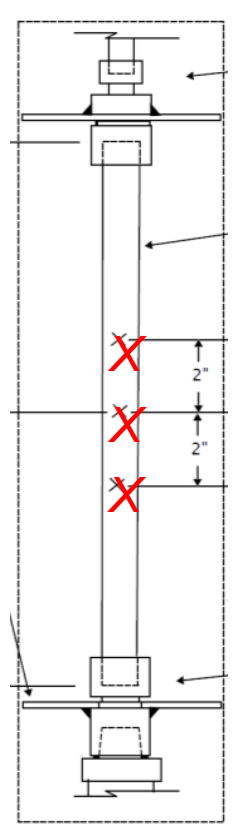

(a)

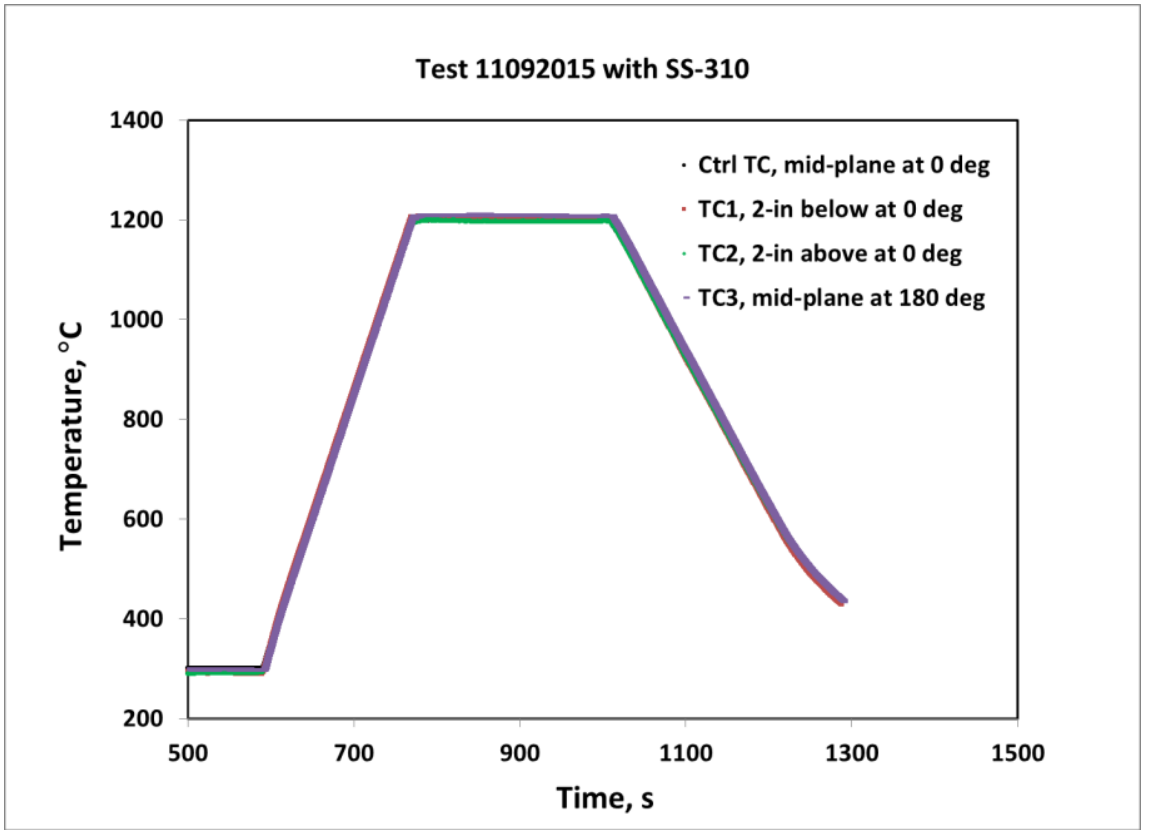

(b)

Figure 7. Verification testing of uniform temperature gradient at specimen centerline, which confirmed good agreement between thermocouple measurements. (a) Four type $\mathrm{S}$ thermocouples two were positioned at the specimen midplane $180^{\circ}$ apart, one was positioned $50 \mathrm{~mm}$ above the midplane, and one was positioned $50 \mathrm{~mm}$ below the midplane. (b) $10^{\circ} \mathrm{C} \Delta T$ among four type $\mathrm{S}$ thermocouples. 
The signal from the top thermocouple is used to control the furnace power to achieve the desired temperature ramp and hold temperature. In-cell testing of fueled samples may be conducted using a strapped thermocouple instead of a welded thermocouple to decrease the likelihood of the thermocouple coming off during the LOCA burst event (Figure 8a,b). Additional comparison of strapped versus welded thermocouple measurements showed a slight $\left(3^{\circ} \mathrm{C}\right)$ difference in the temperature values (Figure $8 \mathrm{c}$ ). These measurements, validating agreement between the two methods, provide confidence that either approach can be used in-cell.

Figure 9 shows a typical temperature and pressure profile for the integral LOCA tests performed on ORNL's SATS.

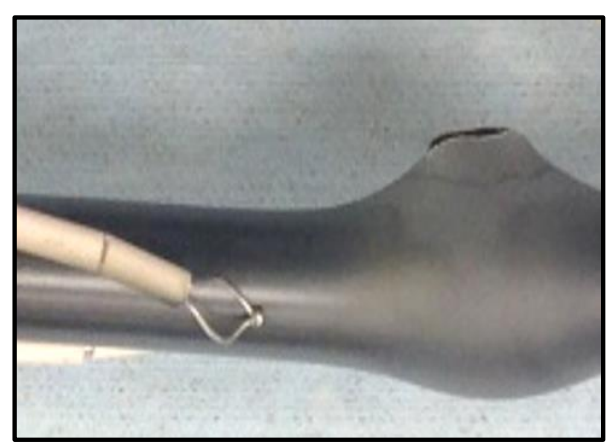

(a)

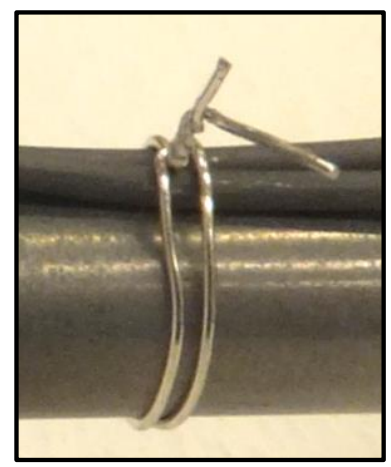

(b)

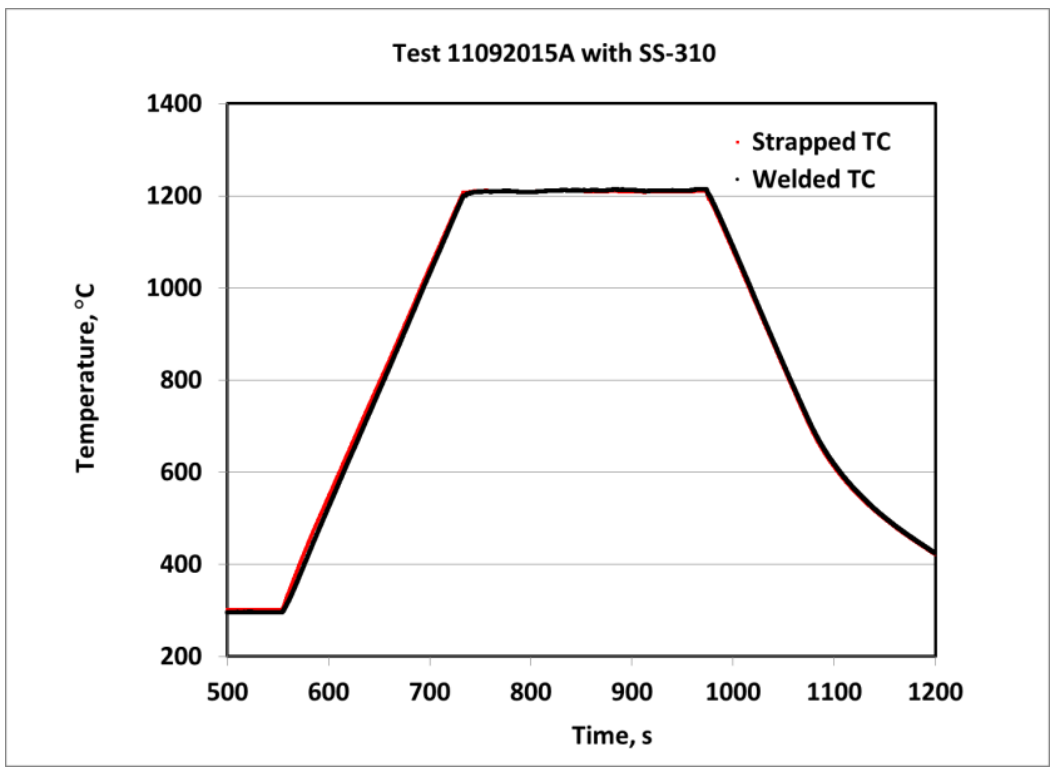

(c)

Figure 8. Comparison testing of strapped versus welded thermocouples. (a) Spot-welded thermocouple. (b) Strapped thermocouple. (c) The graph appears as one line because the temperature difference between the two methods is only $3^{\circ} \mathrm{C}$. These results provide confidence that either method will produce a uniform temperature reading. 


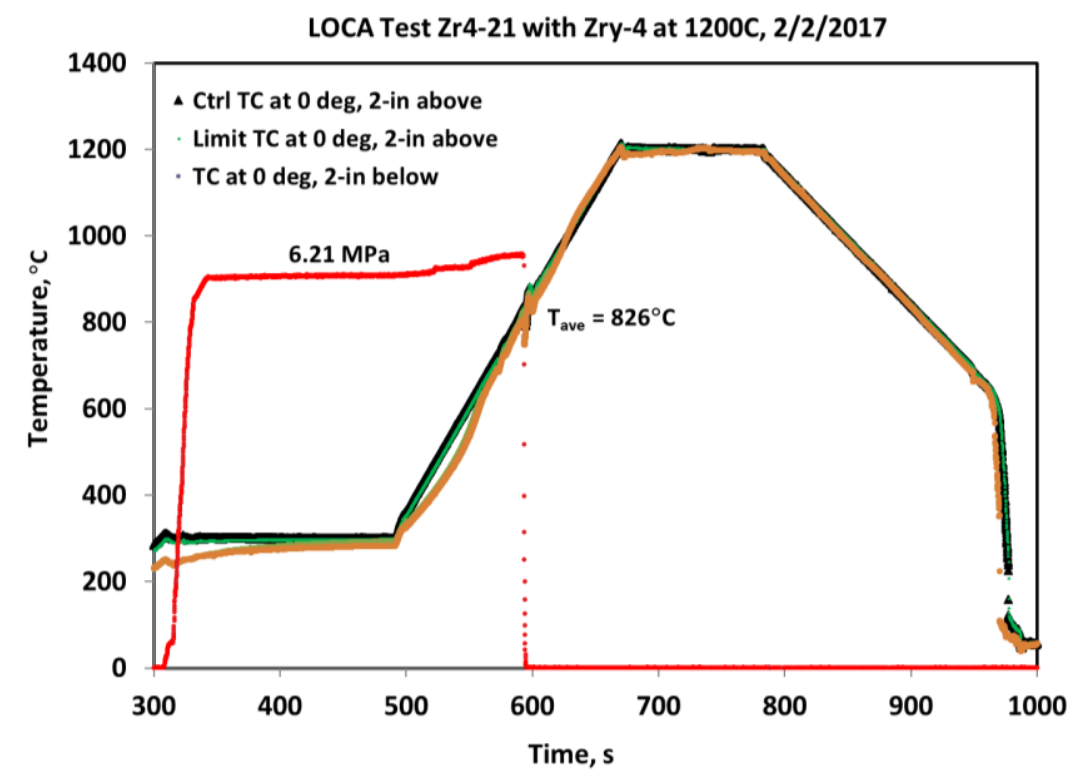

Figure 9. Pressure and temperature histories for LOCA integral test $\mathrm{Zr} 4-21$.

The results from a series of four out-of-cell integral LOCA tests are summarized in Table 3. All four tests were run at $1200^{\circ} \mathrm{C}$, with the only difference being the internal pressure applied. Test Zr4-19 was conducted at $1200^{\circ} \mathrm{C}$ without internal pressure. Test $\mathrm{Zr} 4-23$ was pressurized to $4.14 \mathrm{MPa}$ and burst occurred at $\approx 866^{\circ} \mathrm{C}$. Test $\mathrm{Zr} 4-21$ was pressurized to $6.21 \mathrm{MPa}$ and burst occurred at $826^{\circ} \mathrm{C}$. For Test $\mathrm{Zr} 4-22$, the sample was pressurized to $8.27 \mathrm{MPa}$ and burst occurred at a lower temperature $\left(\approx 790^{\circ} \mathrm{C}\right)$. Figure 10 shows the post-LOCA test samples.

Table 3. LOCA integral test results for unirradiated Zircaloy-4 cladding filled with zirconia pellets

\begin{tabular}{|c|c|c|c|c|}
\hline Parameter & Zr4-19 & Zr4-23 & Zr4-21 & Zr4-22 \\
\hline Internal pressure at $300^{\circ} \mathrm{C}, \mathrm{MPa}$ & 0 & 4.14 & 6.21 & 8.27 \\
\hline Temperature ramp from $300^{\circ} \mathrm{C},{ }^{\circ} \mathrm{C} / \mathrm{s}$ & 5 & 5 & 5 & 5 \\
\hline Peak internal $\mathrm{P}_{\mathrm{g}}, \mathrm{MPa}$ & - & 4.37 & 6.58 & 8.46 \\
\hline Temperature at burst, ${ }^{\circ} \mathrm{C}$ & No burst & 866 & 826 & 790 \\
\hline Hold temperature, ${ }^{\circ} \mathrm{C}$ & 1200 & 1200 & 1200 & 1200 \\
\hline Hold time, s & 287 & 135 & 110 & 90 \\
\hline Cool-down rate to $800^{\circ} \mathrm{C},{ }^{\circ} \mathrm{C} / \mathrm{s}$ & 3 & 3 & 3 & 3 \\
\hline Quench initiation temperature, ${ }^{\circ} \mathrm{C}$ & 700 & 700 & 700 & 700 \\
\hline Burst center relative to midplane, $\mathrm{mm}$ & - & -19 & 31 & -19 \\
\hline Burst shape & - & Dog bone $^{a}$ & Dog bone & Dog bone \\
\hline Burst length, mm & - & 7 & 11 & 9 \\
\hline Maximum burst width, $\mathrm{mm}$ & - & 1.8 & 2.0 & 2.5 \\
\hline Maximum strain $\left[\left(\Delta \mathrm{C} / \mathrm{C}_{\mathrm{m}}\right)_{\max }\right], \%$ & 0 & 27 & 37 & 47 \\
\hline $\begin{array}{l}\text { Reference minimum wall thickness for ECR } \\
\text { calculation, mm }\end{array}$ & 0.57 & 0.45 & 0.42 & 0.39 \\
\hline Target ECR, \% calculated (CP-Model) & 17 & 17 & 17 & 17 \\
\hline
\end{tabular}

${ }^{a}$ Dog-bone shape refers to the burst opening decreasing across the center versus an oval opening that continues to expand across the center of the opening. 

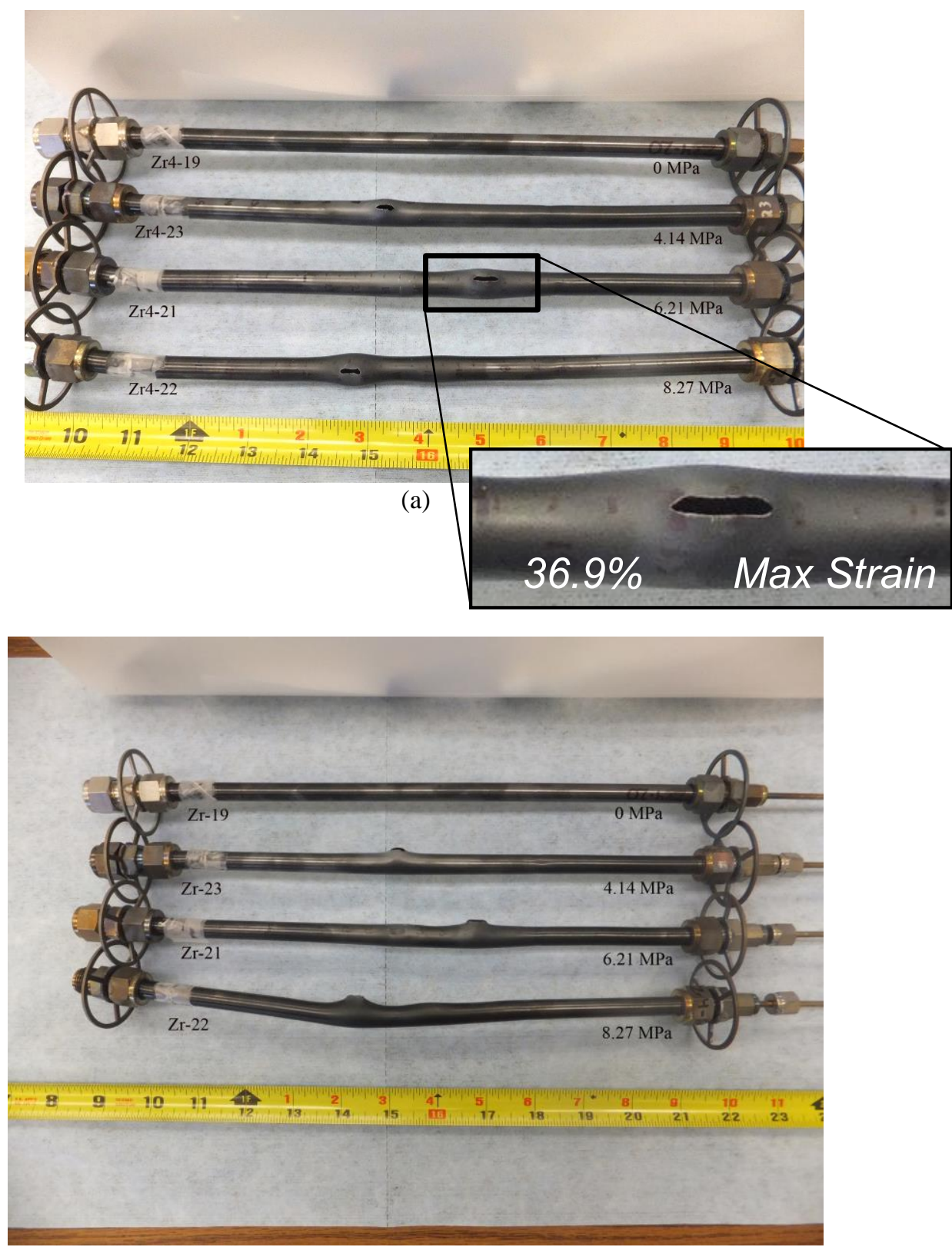

(b)

Figure 10. Top view (a) and side view (b) of four post-LOCA test samples tested at $1200^{\circ} \mathrm{C}$ with internal pressurization of $0.0,4.14,6.21$, and $8.27 \mathrm{MPa}$. Close-up of (a): Zr4-21 at 6.21 MPa burst with maximum strain of $36.9 \%$. All maximum strain values are provided in Table 3 .

Characterization has been performed on post-LOCA test specimens to determine axial profiles of hydrogen pickup, oxygen pickup, and equivalent clad reacted (ECR). Transverse metallography and oxygen analysis have also been done at several axial locations to determine the circumferential variation of metal thickness prior to oxidation and of oxygen pickup. Both microstructure and oxygen concentration results suggest a cross section that varies from very brittle near the burst edges to ductile $180^{\circ}$ from the burst opening. 


\section{HOT CELL INSTALLATION}

When benchmark testing was complete, the SATS system was successfully installed into the main hot cells of the IFEL, Building 3525. The control panel is positioned in the operating area against the outside wall as shown in Figure 11. The corner hot cell workstation provides an optimal location with two windows oriented $90^{\circ}$ apart, one facing north and the other facing west. The dose rate of the SATS workstation was about $70 \mathrm{R} / \mathrm{h}$ prior to preparing the table for this installation (Figure 12a). Removing some radioactive waste material and adding some lead sheets to the tabletop (Figure 12b), reduced the dose rate to $10-15 \mathrm{R} / \mathrm{h}$. The reduction of dose rate in the area will reduce the radiation damage to SATS and extend its operational lifetime.
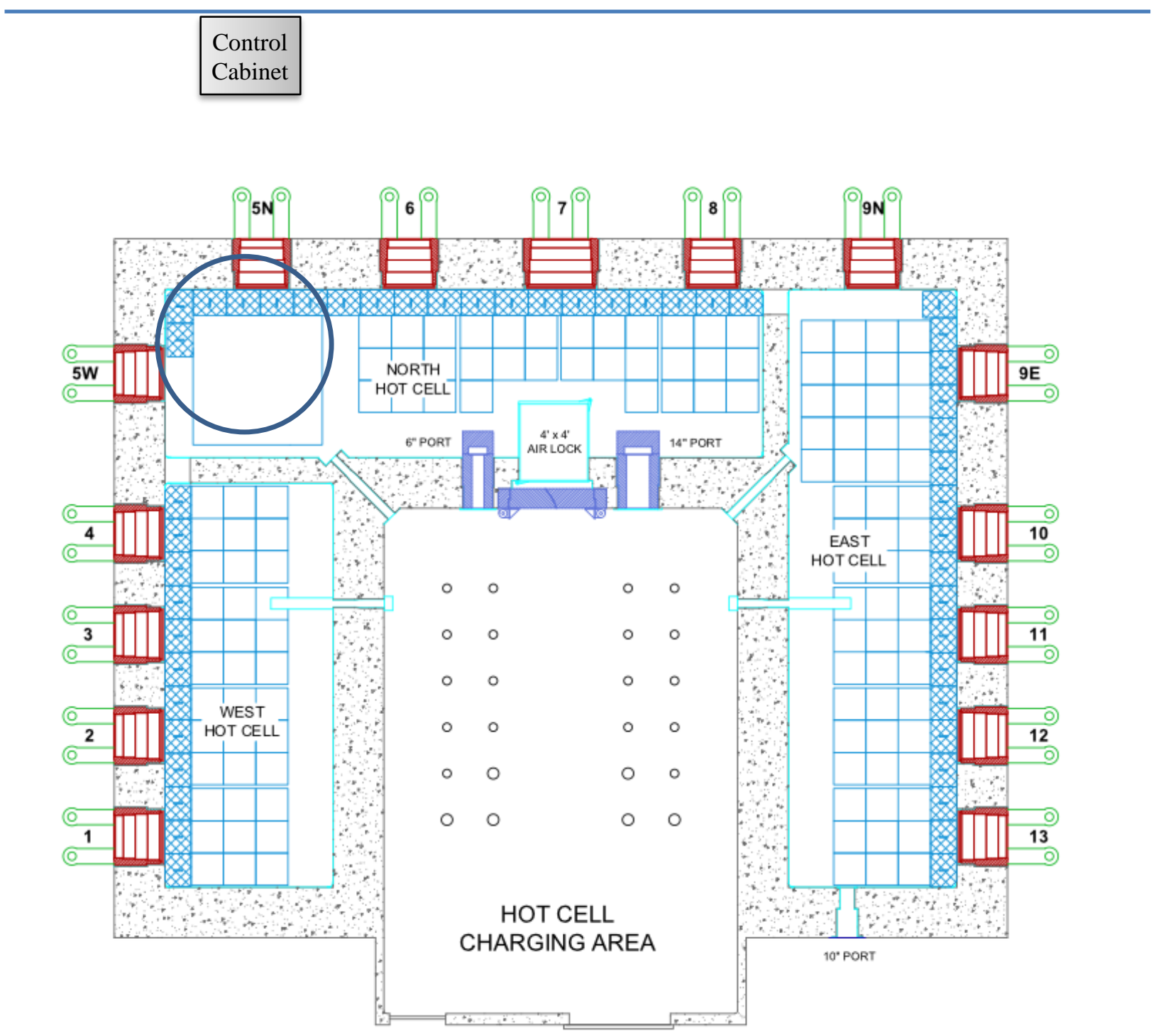

Figure 11. Overhead view of the Irradiated Fuels Examination Laboratory (IFEL), Building 3525. The Severe Accident Test Station faces workstation 5N (circled above) with the control cabinet positioned against the north operating wall. 


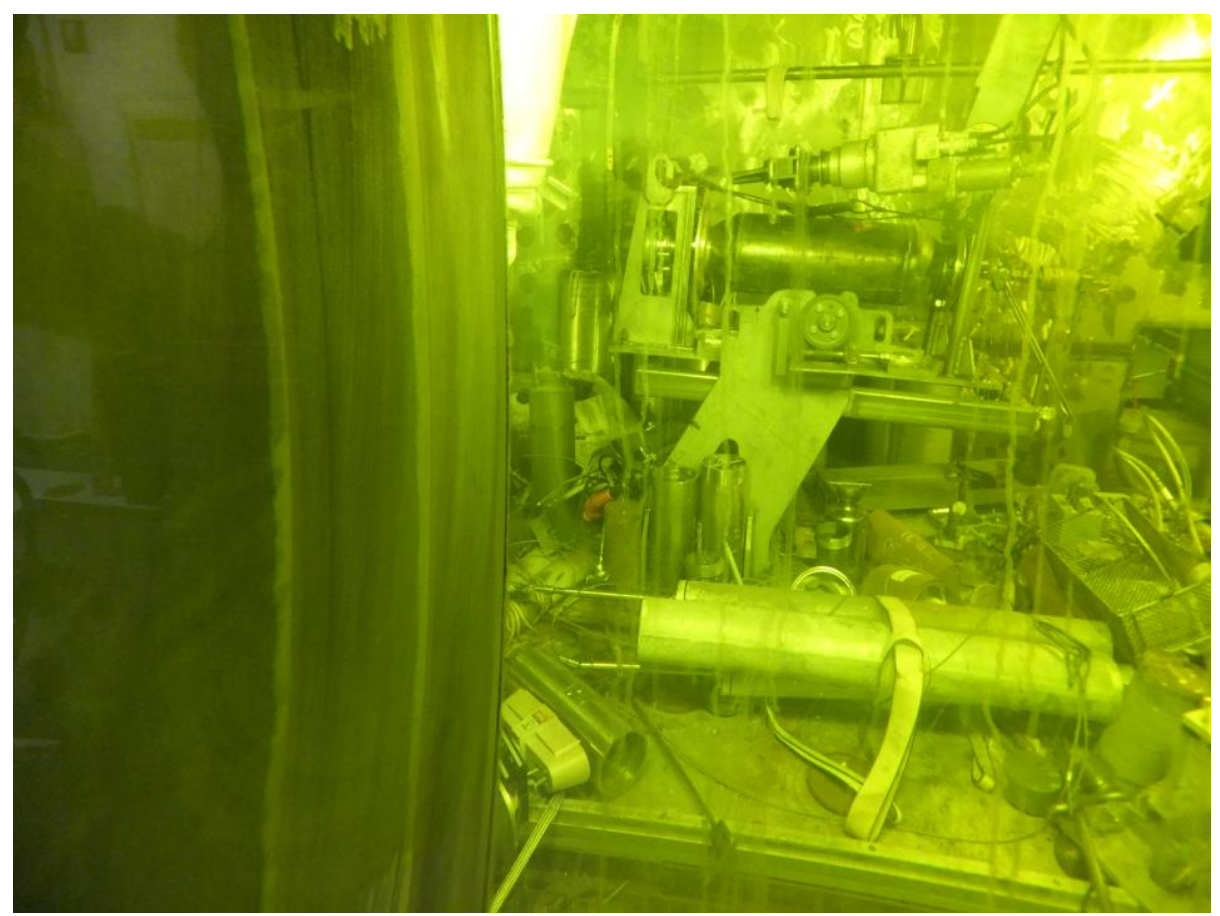

(a)

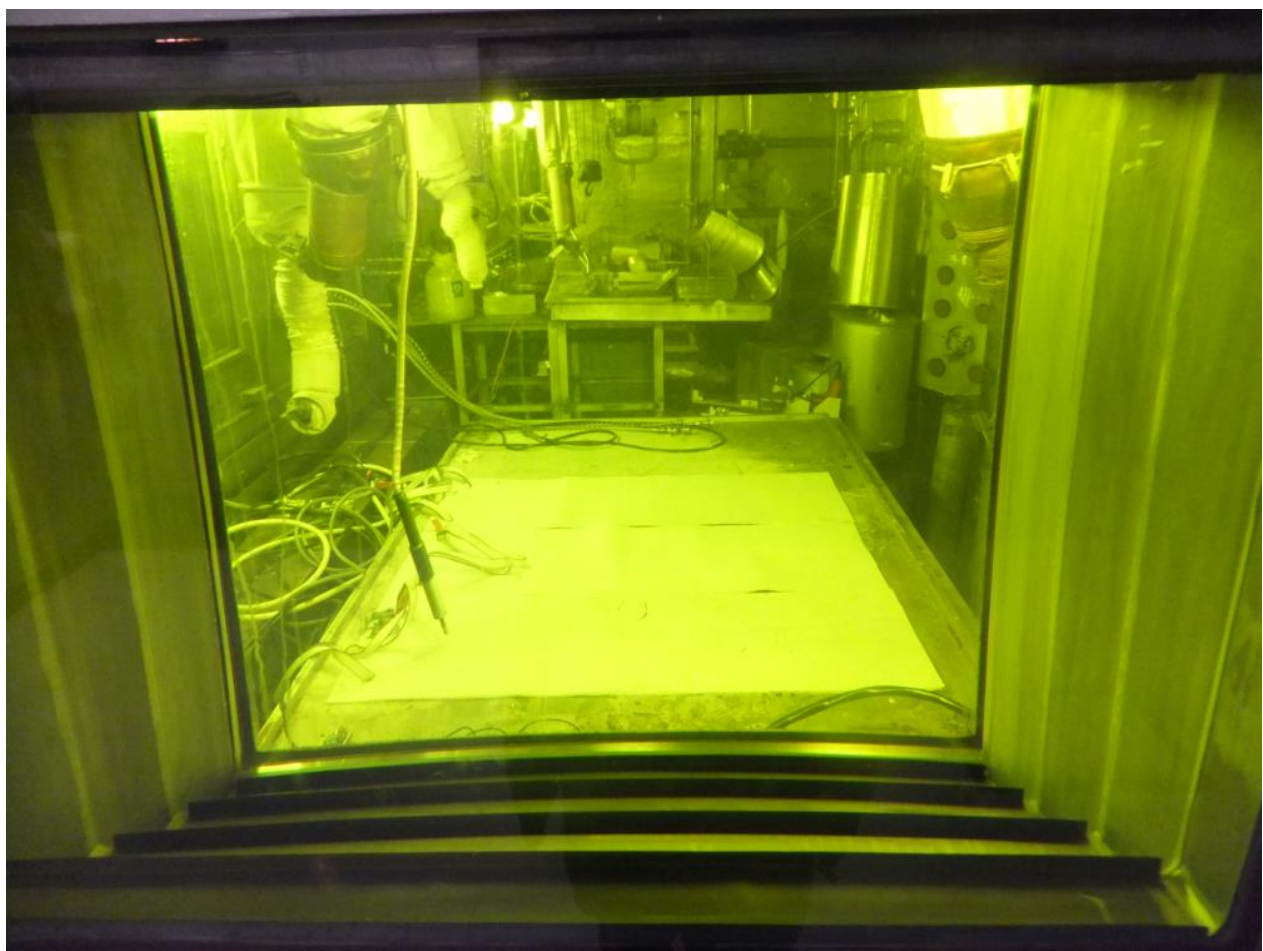

(b)

Figure 12. SATS workstation before (a) and after (b) removing the radioactive materials. A lead sheet (painted white) was placed on the tabletop to reduce the dose rate. 
SATS installation began with the removal of old equipment and waste material (see Figure 12a) located in workstation 5. The in-cell table also required cleaning and additional plates of lead shielding to reduce the dose coming through the table from below (see Figure 12b). Technicians disconnected all cables and pipes running to SATS out-of-cell and handed them over to hot cell operations for preparation of the alpha and lead plugs (Figure 13). Hot cell operators installed three service plugs in the hot cell wall as shown in Figure 14. The control cabinet was moved into the work area across from workstation 5 (see Figure 11). SATS was then lifted and moved through the charging area (Figure 15). Electricians and pipefitters made the out-of-cell utility connections of cables and pipes (Figure 16) after the cooling system, high-pressure system, and inert gas cylinder were placed in the area next to workstation 5 (Figure 17). Finally, the hot cell operators made the connections of lines in-cell to the SATS system.

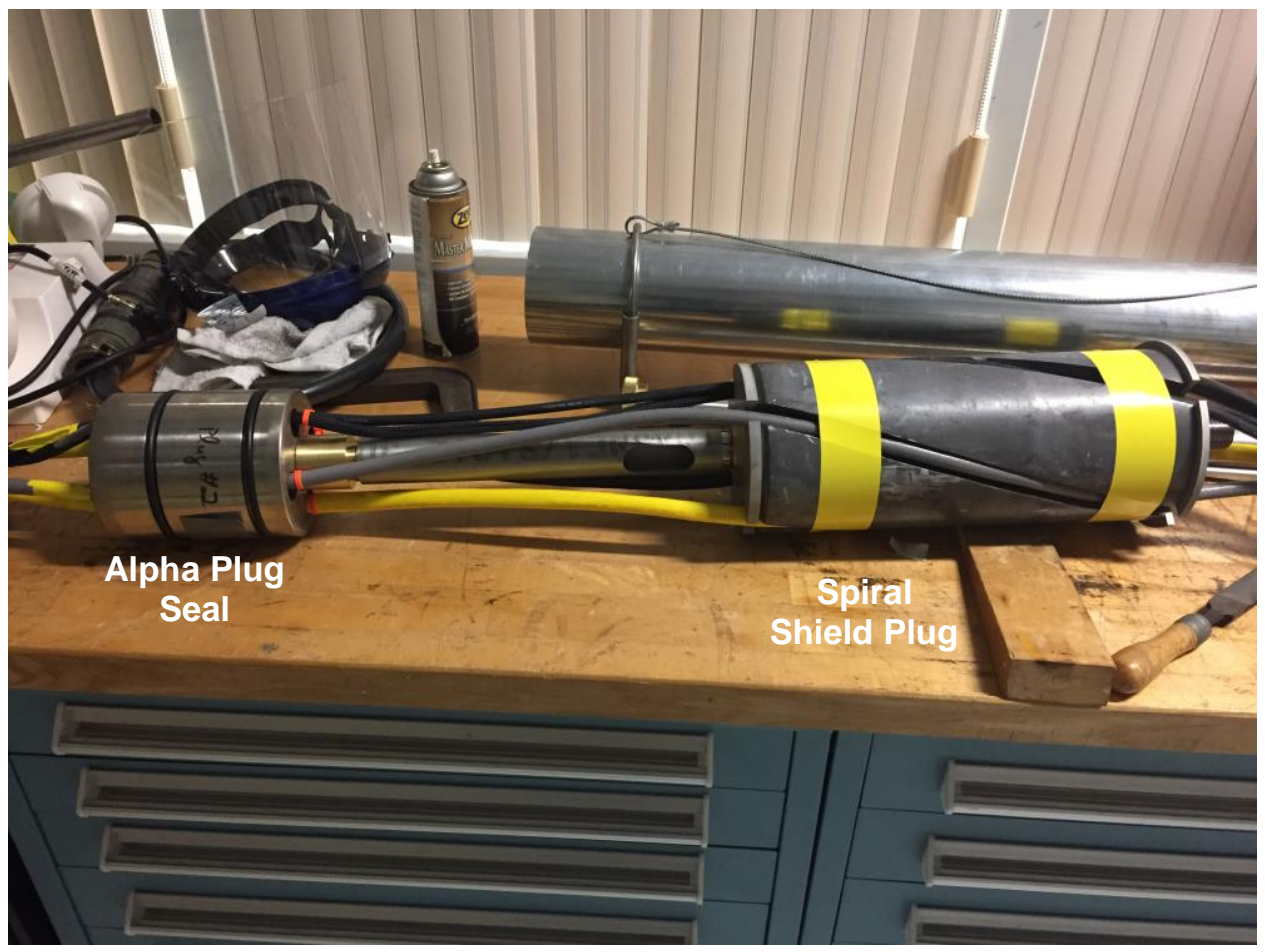

Figure 13. A service plug for power line penetration through the hot cell wall.
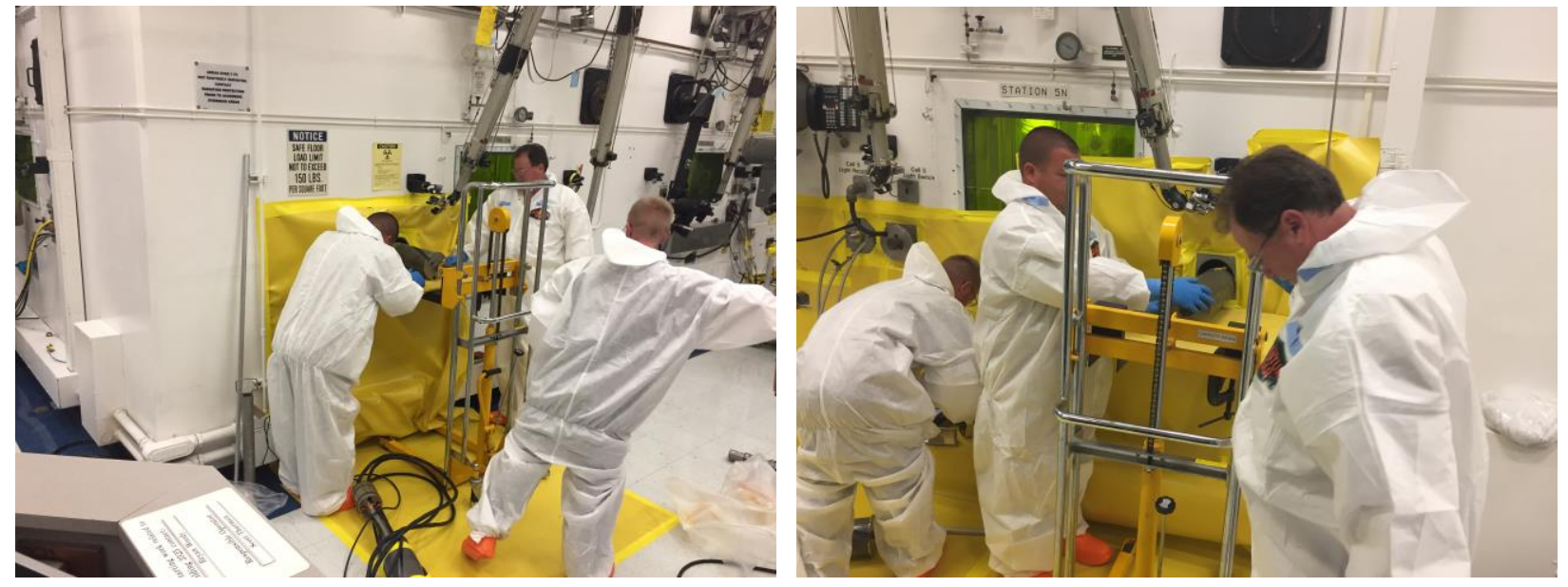

Figure 14. Installation of a service plug for SATS into the hot cell wall. 


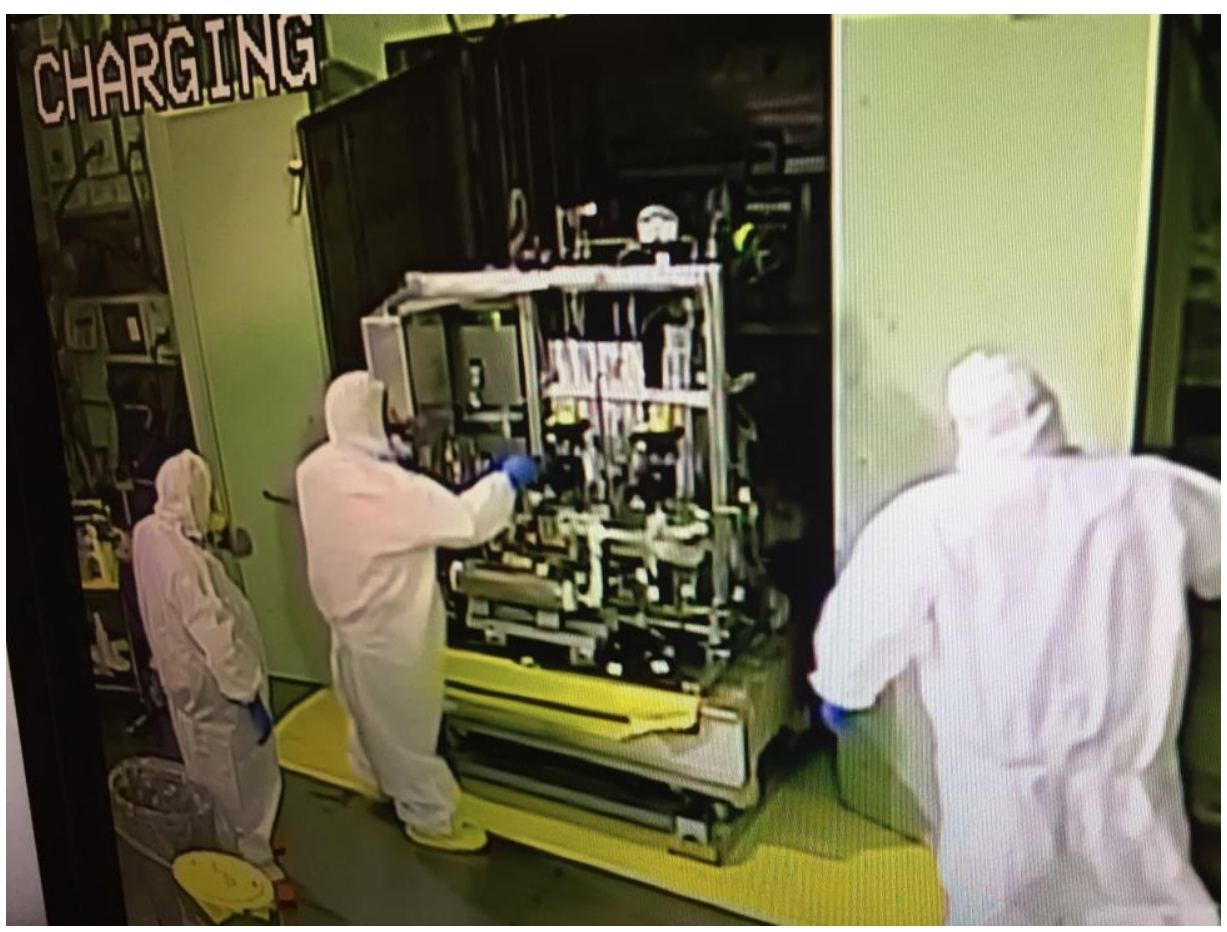

Figure 15. Installation of SATS into the main hot cell of the IFEL.

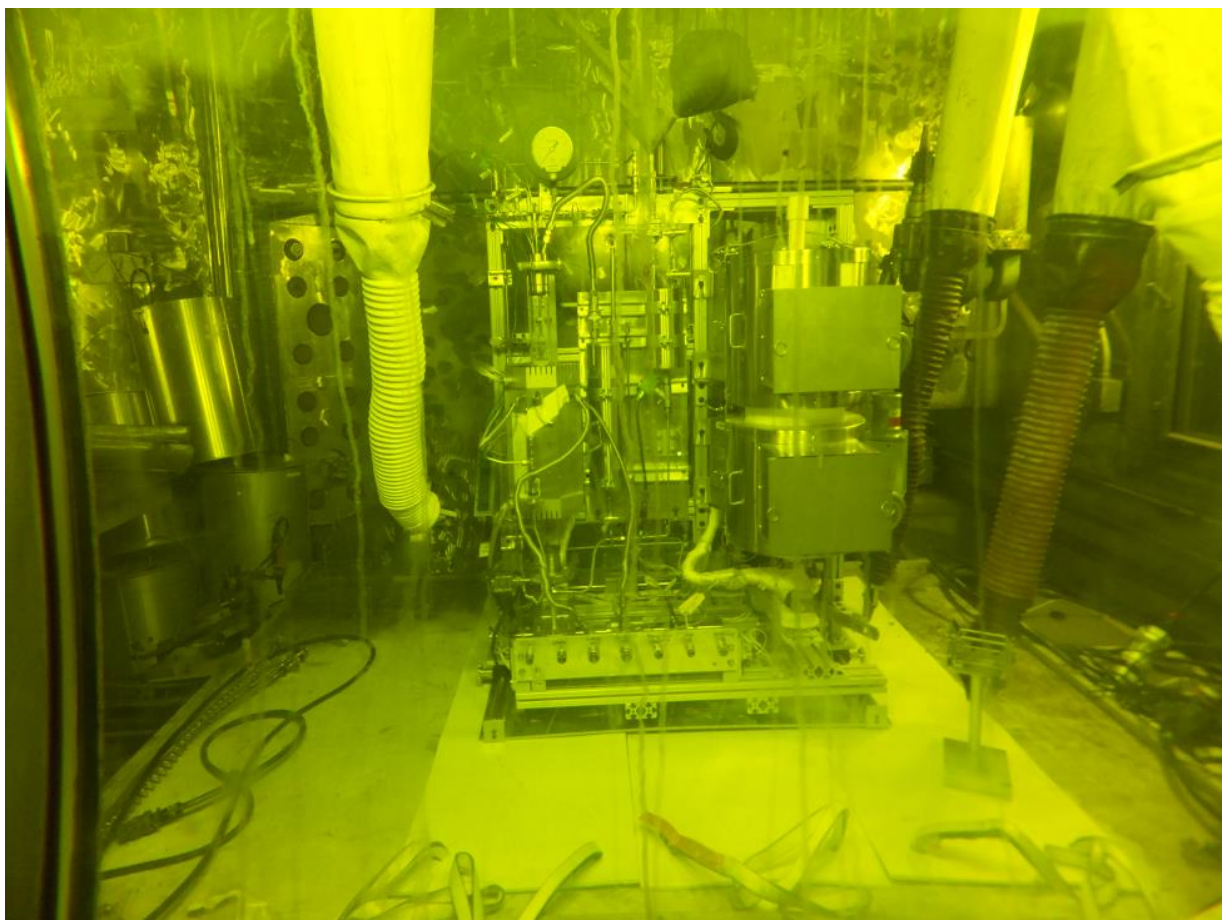

Figure 16. SATS in the main hot cell of the IFEL. 


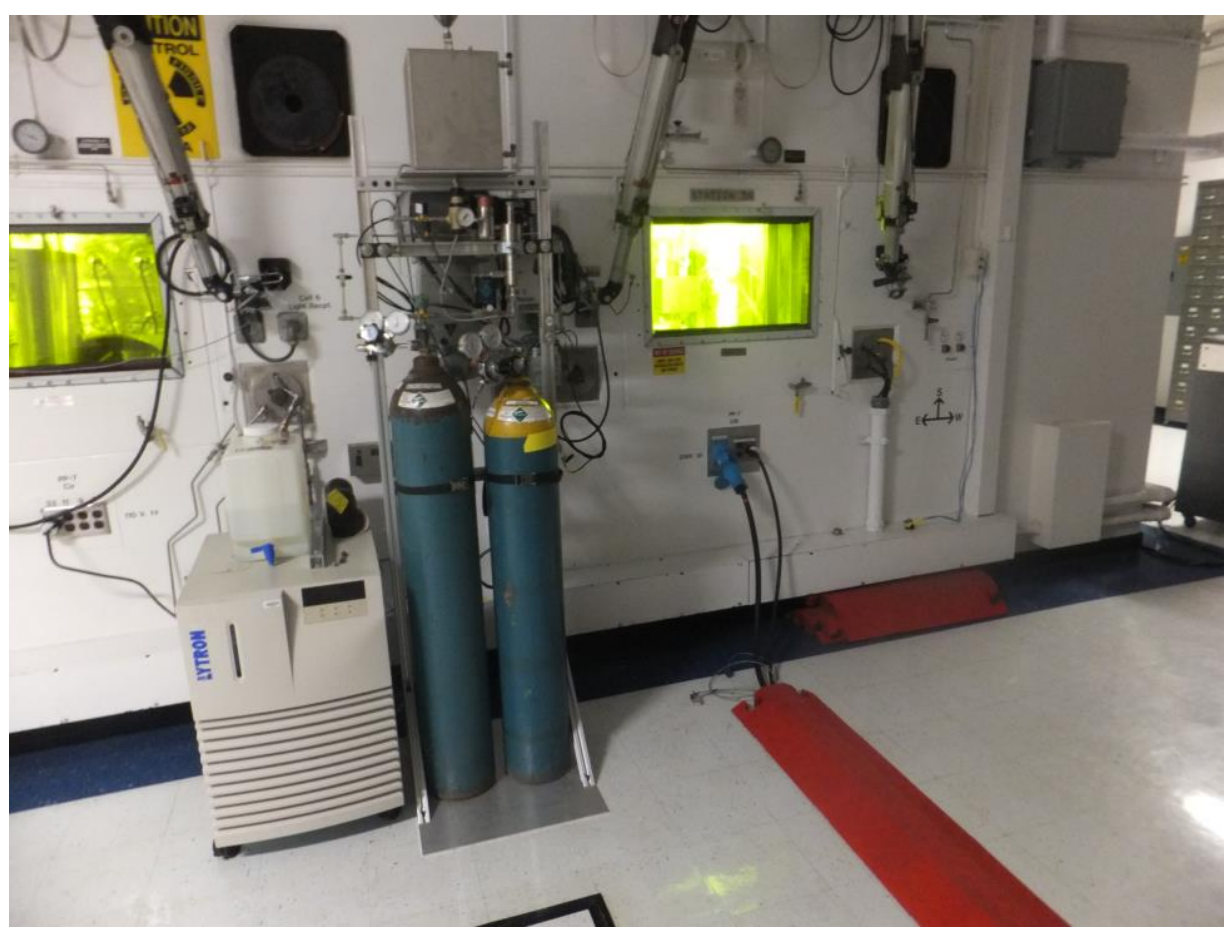

Figure 17. Water cooling system and high-pressure system for the in-cell LOCA apparatus. 


\section{SATS DEMONSTRATION TEST RESULTS}

This section describes the demonstration test results obtained from in-cell testing of unirradiated samples.

\subsection{LOCA Demonstration Test Results}

After successfully installing the SATS system into the hot cell, the LOCA furnace was aligned to aid in optimizing the apparatus and the test train for remote operation in the hot cell. Figure 18 shows a LOCA sample within the test chamber (a quartz tube). The quartz tube encasing the test train provides an enclosed volume for steam flow and water quench, both of which are introduced through the bottom of the test train. Four type $S$ thermocouple lead wires were fed in through the top flange: two were positioned at the specimen midplane $180^{\circ}$ apart, one was positioned $50 \mathrm{~mm}$ above the midplane, and one was positioned $50 \mathrm{~mm}$ below the midplane. The signal from the top thermocouple is used to control the furnace power to achieve the desired temperature ramp and the hold temperature.

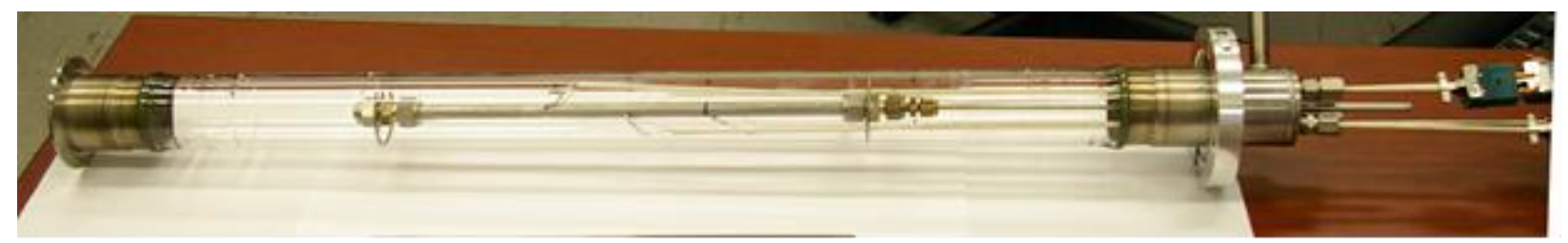

Figure 18. A LOCA test train within a quartz tube.

A full sequence LOCA test was conducted with the SATS system on August 7, 2017 (Figure 19). A LOCA integral test with 300-mm-long samples consists of the following sequential steps: stabilize temperature, internal pressure, and steam flow at $300^{\circ} \mathrm{C}$; ramp the temperature $\left(\approx 5^{\circ} \mathrm{C} / \mathrm{s}\right)$ through ballooning and burst to $\approx 1200^{\circ} \mathrm{C}$; hold at $1200^{\circ} \mathrm{C}$ for $1-5 \mathrm{~min}$; slow cool $\left(\approx 3^{\circ} \mathrm{C} / \mathrm{s}\right)$ to $700-800^{\circ} \mathrm{C}$; and finally water quench. Figure 20 shows the temperature and pressure profile for integral LOCA test $\mathrm{Zr} 4-$ 26, performed on the in-cell SATS.

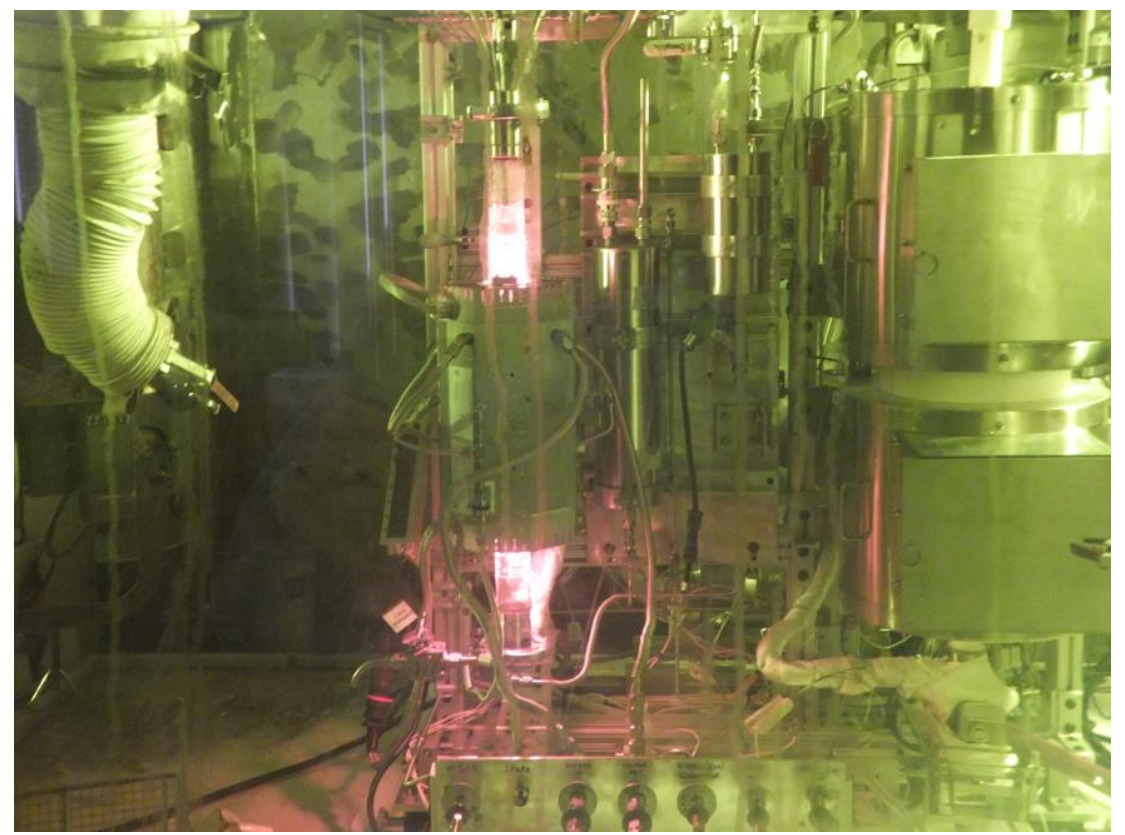

Figure 19. LOCA in-cell demonstration test in the IFEL. 


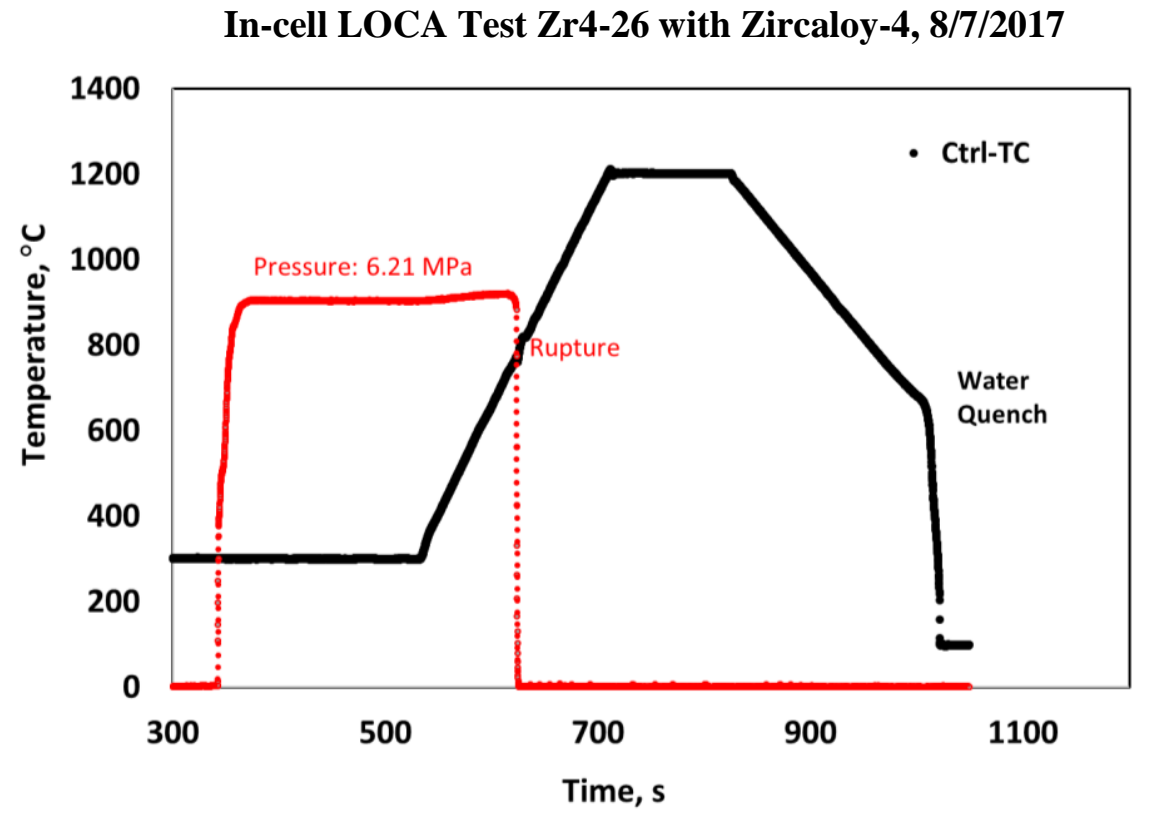

Figure 20. Pressure and temperature histories for in-cell LOCA integral test Zr4-26.

\subsection{High-Temperature Furnace Demonstration Test Results}

In addition to LOCA testing, a high-temperature steam oxidation test was conducted with SATS's hightemperature furnace (Figure 21). The target temperature was $1400^{\circ} \mathrm{C}$, and the furnace was ramped at a controlled heating rate of $15^{\circ} \mathrm{C} / \mathrm{min}$.

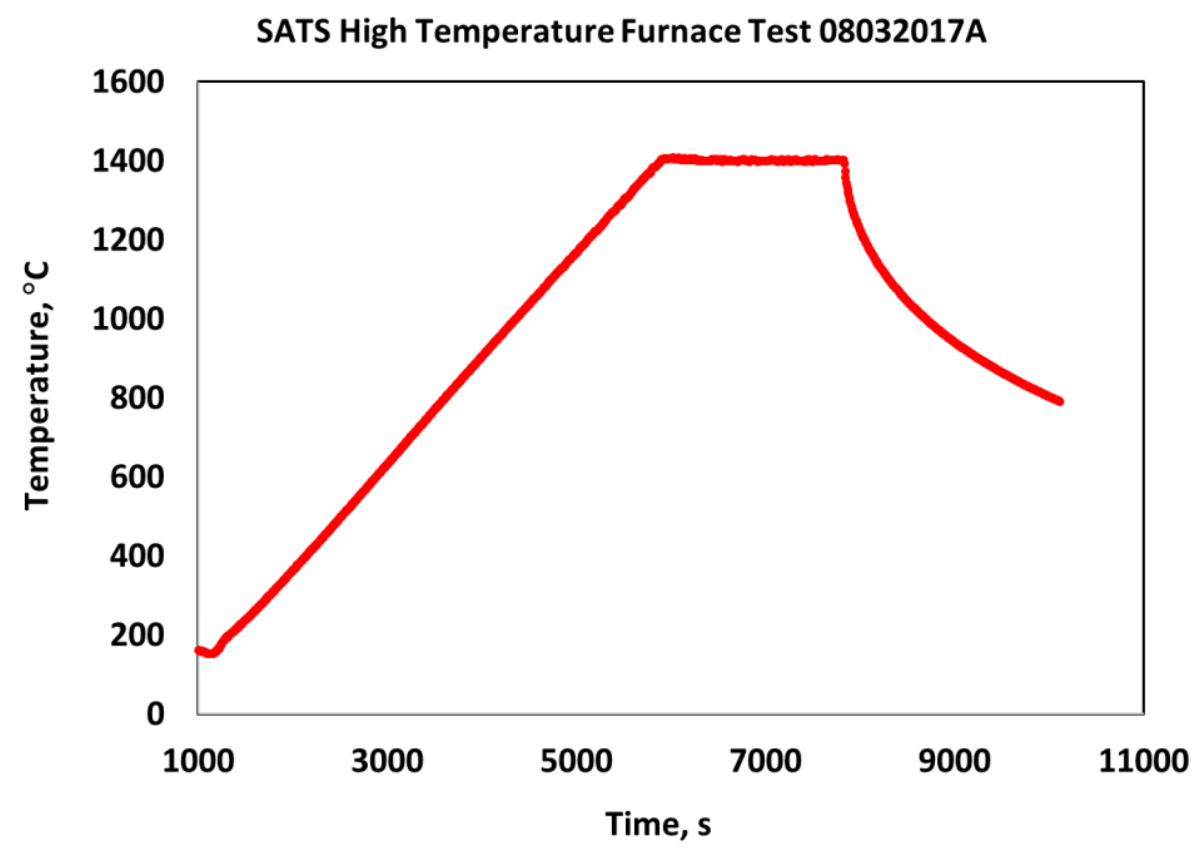

Figure 21. Temperature history for the in-cell high-temperature steam oxidation test performed August 3, 2017. 


\section{SUMMARY AND FUTURE WORK}

The Severe Accident Test Station (SATS) was successfully installed and demonstrated in the Irradiated Fuels Examination Laboratory at ORNL. The test facility is designed to examine fuel and cladding response to LOCA transients during design basis accident and beyond design basis accident scenarios by exposing irradiated samples to various in-core conditions, including high temperatures, steam, and the direct quench anticipated during emergency core cooling. This document reports on the first use of the integral test facility and the results obtained for unirradiated Zircaloy-4. It also details the installation process and test setup.

Future test plans include in-cell benchmarking testing using commercial Zr-based alloys, hightemperature oxidation of fueled ATF-1 rodlets, and separate effects testing ahead of the Transient Reactor Test Facility (TREAT) in-core experiments summarized below.

The ATF-1 rodlets, which were irradiated in the Advanced Test Reactor (ATR) at Idaho National Laboratory (INL), consist of FeCrAl cladding and $\mathrm{UO}_{2}$ (Figure 22). The rodlets have undergone initial post-irradiation examination at INL and have been prepared for shipment to ORNL. The rodlets include holes to permit hanging in the SATS high-temperature furnace and will provide the first data on fuelcladding interaction and the fueled severe accident response of FeCrAl cladding.

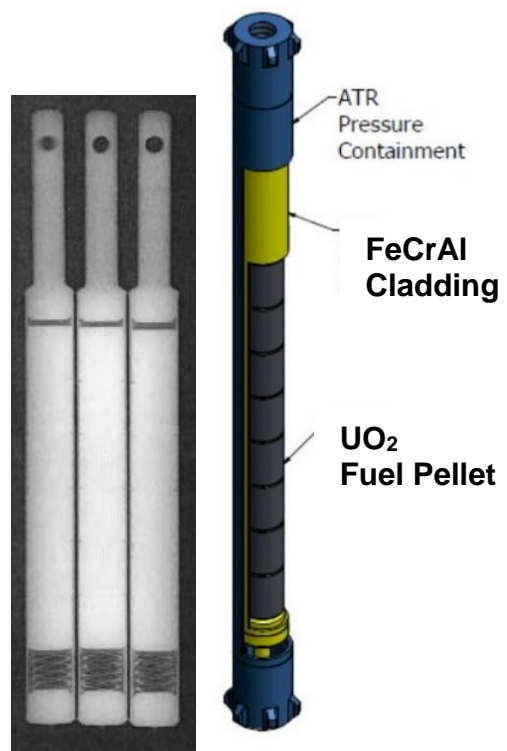

Figure 22. ATF-1 rodlet irradiated in ATR, with $\mathrm{FeCrAl}$ cladding and $\mathrm{UO}_{2}$ pellets designed for post-irradiation testing using SATS.

A successful Nuclear Science User Facility proposal by the Electric Power Research Institute and the US Nuclear Regulatory Commission [14] will utilize SATS to benchmark LOCA high-burnup target fuels out-of-core; these fuels will be reconditioned into rodlets for higher burnup in ATR. The final in-pile LOCA simulation will be performed on the TREAT Super-Static Environment Rodlet Transient Testing Apparatus (Super-SERTTA) irradiation test device at INL. 


\section{REFERENCES}

[1] L. Baker and L. C. Just, Studies of Metal-Water Reactions at High Temperatures: III. Experimental and Theoretical Studies of the Zirconium-Water Reaction, report ANL-6548, Argonne National Laboratory, May 1962.

[2] J. V. Cathcart, R. E. Pawel, R. A. McKee, R. E. Druschel, G. J. Yurek, J. J. Cambell, and S. H. Jury, Zirconium Metal-Water Oxidation Kinetics: IV. Reaction Rate Studies, report ORNL/NUREG-17, Oak Ridge National Laboratory, August 1977.

[3] Y. Yan, R. V. Strain, T. S. Bray, and M. C. Billone, High Temperature Oxidation of Irradiated Limerick BWR Cladding, report NUREG/CP-0176, US Nuclear Regulatory Commission, May 2002, pp. 353-372.

[4] F. Nagase, T. Otomo, and H. Uetsuka, "Oxidation kinetics of low-Sn Zircaloy at the temperature range from 773 to $1571 \mathrm{~K}$," Nucl. Sci. Technol. 40, 213-219 (2003).

[5] M. Billone, Y. Yan, T. Burtseva, and R. Daum, Cladding Embrittlement during Postulated Loss-ofCoolant Accidents, report NUREG/CR-6967, ANL-07/04, US Nuclear Regulatory Commission and Argonne National Laboratory, July 2008.

[6] J.-P. Mardon, D. Charquet, and J. Senevat, "Influence of composition and fabrication process on outof-pile and in-pile properties of M5 alloy," pp. 505-524 in Zirconium in the Nuclear Industry: 12th International Symposium, ASTM STP 1354, G. P. Sabol and G. D. Moan, Eds., American Society for Testing and Materials, 2000.

[7] R. J. Comstock, G. Schoenberger, and G. P. Sabol, "Influence of Processing variables and alloy chemistry on the corrosion behavior of ZIRLO nuclear fuel cladding," pp. 710-725 in Zirconium in the Nuclear Industry: 11th International Symposium, ASTM STP 1295, E. R. Bradley and G. P. Sabol, Eds., American Society for Testing and Materials, 1996.

[8] Y. Yan, T. Burtseva, and M. Billone, "High-temperature steam-oxidation behavior of $\mathrm{Zr}-1 \mathrm{Nb}$ cladding alloy E110," J. Nucl. Mater. 393, 433-448 (2009).

[9] K. Svaholm et al., "Halden reactors IFA-511.2 and IFA-54X: experimental series under adverse cooling conditions," Exper. Thermal Fluid Sci. 11 (1995).

[10] P. D. Parson, E. D. Hindle, and C. A. Mann, PWR Fuel Behavior in Design Basis Accident Conditions, A State-of-the-Art Report by the Task Group on Fuel Behavior of CSNI Principle Work Group 2, CSNI Report 129, Committee on the Safety of Nuclear Installation, OECD Nuclear Energy Agency.

[11] Nika Helin and Johan Flygare, NRC LOCA Tests at Studsvik-Design and Construction of Test Train Device and Tests with Unirradiated Cladding Material, report STUDSVIK/N-11/130, Studsvik Nuclear AB, 2012.

[12] M. Snead, Y. Yan, M. Howell, J. Keiser, and K. Terrani, Severe Accident Test Station Design Document, Oak Ridge National Laboratory, 2015.

[13] Y. Udagawa, F. Nagase, and T, Fuketa, "Effect of cooling history on cladding ductility under LOCA conditions," J. Nucl. Sci. Technol. 43(8), 844-850 (2006).

[14] K. Yueh and M. Bales, "Irradiation, transient testing and post irradiation examination of ultra high burnup fuel,” Technical Abstract CFA-17-12985, NSUF-2 Access, Nuclear Fuel Behavior and Advanced Nuclear Fuel Development program, Electric Power Research Institute. 